\title{
CARBONATITIC VERSUS HYDROTHERMAL ORIGIN FOR FLUORAPATITE REE-Th DEPOSITS: EXPERIMENTAL STUDY OF REE TRANSPORT AND CRUSTAL “ANTISKARN" METASOMATISM
}

\author{
MICHAEL ANENBURG* ${ }^{*}{ }^{\dagger}$ and JOHN A. MAVROGENES $*, \S$
}

\begin{abstract}
Nolans-type ore deposits contain REE and Th mineralization hosted in fluorapatite veins. These veins intrude granulite facies rocks and are surrounded by a diopside selvage. Nolans-type deposits are thought to form by REE, F and P-rich hydrothermal fluids derived from alkali or carbonatitic intrusions. However, REE are not effectively transported in F and P-rich systems. REE ore deposits are commonly hydrothermally overprinted, possibly obscuring the igneous nature of the primary mineralization. We conducted a series of piston cylinder "sandwich" experiments, testing the hydrothermal fluid hypothesis, and a newly suggested process of carbonatite metasomatism. Our results confirm theoretical predictions that REE are hydrothermally immobile in these systems and the experimental phase assemblage is not compatible with the natural rocks. Our results show that fluorapatite can only host several weight percent levels of REE at temperatures higher than $\sim 600{ }^{\circ} \mathrm{C}$. Below that temperature, a miscibility gap exists between REE-poor fluorapatite and REE-rich silicates such as britholite or cerite. In contrast, experiments reacting $\mathbf{P}$ and REE-rich carbonatite with silicate rock above $700{ }^{\circ} \mathrm{C}$ closely resemble natural rocks from Nolans-type deposits. Selvage mineralogy is sensitive to the $\mathrm{MgO}$ content of the carbonatite. A diopside selvage formed at carbonatite $\mathrm{MgO} /(\mathrm{CaO}+\mathrm{MgO}) \approx 0.2$ while wollastonite and forsterite formed at lower and higher ratios, respectively. Phosphate solubility in carbonatites decreases with decreasing $\mathrm{MgO}$ contents. As diopside formed, REE-rich fluorapatite preferentially crystallized from the selvage inwards. Thus, carbonatites are effective at simultaneously mobilizing REE, $F$ and $P$ to the site of deposition. Nolans-type deposits are the cumulate residue of this reaction, with the carbonatite liquid migrating elsewhere. At temperatures below $700{ }^{\circ} \mathrm{C}$ the carbonatitesilicate reaction additionally formed monticellite, cuspidine and magnesioferrite, resembling a skarn assemblage. Whereas skarns form by infiltration of silicate magmas or related fluids to carbonate rocks, our experiments are the opposite: intrusion of carbonatite into silicate rock. These mid-crustal skarn-like rocks may host elevated ore elements of carbonatitic affinity, such as F, P, Y, REE, Th, Ba, Sr, and Nb. We propose the term "antiskarn" to describe such systems, and suggest they trace the migration of carbonatite liquids through the crust. Hydrothermal reworking, retrogression, or metamorphism of antiskarns may obscure the carbonatitic genesis of the rocks. These metasomatic zones are the crustal equivalent of wehrlites that form by peridotitecarbonatite reaction at mantle depths.
\end{abstract}

Key words: Carbonatite, metasomatism, decarbonation, rare earth element, skarn, fluorapatite

GLOSSARY OF SYMBOLS

List of mineral and other abbreviations used in the figures and tables of this work. We followed the recommendations of Whitney and Evans (2010) where possible.

ab: albite

act: actinolite

aln: allanite

bc: barytocalcite

bm: barian-mica

\footnotetext{
* Research School of Earth Sciences, Australian National University, Acton 2601 ACT, Australia

† Corresponding author: michael.anenburg@anu.edu.au

§ john.mavrogenes@anu.edu.au
} 


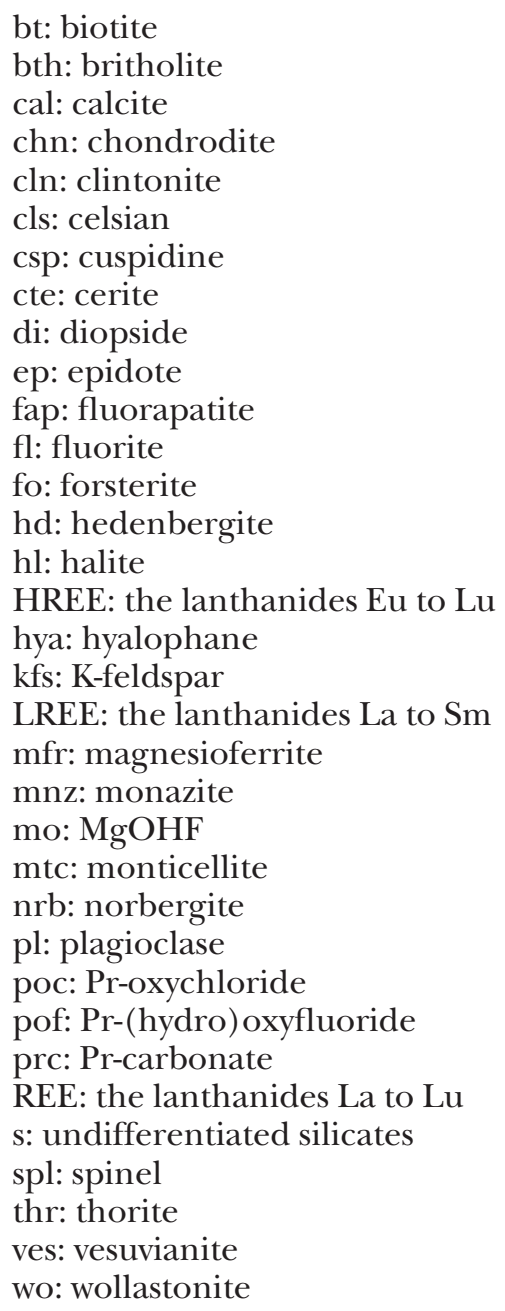

INTRODUCTION

The rare earth elements are a group of metals increasingly used in modern technological applications (Hoatson and others, 2011; Atwood, 2012; Chakhmouradian and Zaitsev, 2012; Linnen and others, 2014; Wall, 2014). Historically, production came from a small set of deposits, and research and exploration for new deposit types has been limited (Chakhmouradian and Zaitsev, 2012; Verplanck and others, 2016) The classification of REE as "critical metals" (Chakhmouradian and Zaitsev, 2012; Vidal and others, 2013; Nassar and others, 2015) and the need to secure new sources for these elements has spawned numerous exploration and research projects (Wall, 2014; Weng and others, 2015). New types of REE deposits are being discovered and incomplete understanding of these new types may cause confusion regarding their mode of genesis, tectonic setting and classification, resulting in impaired exploration targeting.

A recently identified REE ore deposit type is the Nolans-type, named after the type locality at Nolans Bore, Northern Territory, Australia (Schoneveld and others, 2015; Huston and others, 2016). This deposit type is characterized by centimeter to meter wide veins or dikes dominated by fluorapatite, hosting up to 5 percent by weight of REE contents via the charge balanced substitution 


$$
\mathrm{Ca}^{2+}+\mathrm{P}^{5+}=\mathrm{REE}^{3+}+\mathrm{Si}^{4+}
$$

known as the "britholite" component in apatite (Pan and Fleet, 2002). Other notable examples of the Nolans-type deposits are Hoidas Lake, Saskatchewan, Canada (Hogarth, 1957; Pandur and others, 2014; Pandur and others, 2016) and Kasipatnam, Andhra Pradesh, India (Narasayya and Sriramadas, 1974; Choudhuri and Banerji, 1976; Rao, 1976; Panda and others, 2015). Deposit type hosts LREE with significant Th contents. The relative proportion of $\mathrm{Nd}$ and $\mathrm{Pr}$ is high, unlike other LREE deposits dominated by La and Ce, strengthening the economic attractiveness of this type. The fluorapatite veins are hosted in high metamorphic grade terranes of amphibolite or granulite facies with spatially associated felsic plutonic activity. The contact between the veins and host rocks consists of diopside selvages, centimeter to meters thick, with hyalophane-bearing zones (for example, Hogarth, 1957; Narasayya and Sriramadas, 1974; Choudhuri and Banerji, 1976; Rao, 1976).

The REE-rich fluorapatite is almost completely altered to REE-poor apatite and a plethora of secondary REE silicates, phosphates and carbonates (Panda and others, 2015; Schoneveld and others, 2015; Anenburg and others, 2018). Secondary silicates commonly host considerable Th in addition to the REE. Allanite occurs between the fluorapatite veins and diopside selvages, and as patches or veins cross-cutting the fluorapatite zones. The diopside selvages are commonly altered to a secondary assemblage of amphibole, epidote and grandite garnet (Schoneveld and others, 2015; Huston and others, 2016).

The formation of Nolans-type deposits is not currently well understood. Nolans Bore has been classified as hydrothermal, alkali, carbonatitic, metasomatic and combinations thereof (Orris and Grauch, 2002; Hoatson and others, 2011; Weng and others, 2013; Jaireth and others, 2014; Linnen and others, 2014; Wall, 2014; Schoneveld and others, 2015; Weng and others, 2015; Huston and others, 2016), or simply as an "unknown" type (Simandl, 2014). The most detailed study to date (Huston and others, 2016) suggested that Nolans Bore formed by P-bearing hydrothermal fluids derived from alkali magmas. Similarly, Hoidas Lake has been classified into a non-genetic "monazite \pm apatite vein" group (Simandl, 2014). Narasayya and Sriramadas (1974) initially suggested a carbonatitic origin for Kasipatnam, but that idea was later challenged (Choudhuri and Banerji, 1976; Rao, 1976).

Nolans-type deposits are dominated by $\mathrm{P}$, which is known to be an ineffective ligand for the transport of REE in aqueous fluids (Pourtier and others, 2010; Louvel and others, 2015; Zhou and others, 2016), and the solubility of apatite is rather low except in highly saline brines (Antignano and Manning, 2008). Sodium can facilitate the uptake of REE by fluorapatite via the following reaction:

$$
2 \mathrm{Ca}^{2+}=\mathrm{Na}^{+}+\mathrm{REE}^{3+},
$$

but $\mathrm{Na}$ is found only in trace amounts in Nolans-type apatite (Pandur and others, 2016), contrary to the ubiquity of this substitution vector in alkali rocks (Larsen, 1979). The total absence of sodic or potassic alteration (fenitization), so conspicuously common around alkali intrusions (silicate and carbonatite alike) and their hydrothermal offshoots (Pirajno, 2013), leads one to question the role of alkali magmas or fluids in the formation of Nolans-type deposits. Both Nolans Bore and Hoidas Lake have been suggested to form by distal carbonatite-derived hydrothermal fluids (Huston and others, 2016; Pandur and others, 2016). However, similar systems elsewhere are rich in the HREE such as the Bear Lodge complex (Andersen and others, 2016), Lofdal (Bodeving and others, 2017), Malawi (Broom-Fendley and others, 2016; BroomFendley and others, 2017), whereas Nolans Bore and Hoidas Lake are nearly devoid of HREE. The apatite-diopside association is known from phoscorites, but phoscorites 
also contain abundant magnetite, which is absent from Nolans-type deposits (Krasnova and others, 2004). Phoscorites are also part of larger scale alkaline-carbonatite intrusive complexes, unlike the isolated Nolans-type deposits. Finally, apatite from phoscorites contains low REE contents compared to Nolans-type apatite (Krasnova and others, 2004; Zaitsev and others, 2014).

\section{REE TRANSPORT IN HYDROTHERMAL FLUIDS}

REE were not traditionally considered hydrothermally mobile, but recent studies indicate aqueous fluid transport is possible, given proper complexing ligands (WilliamsJones and others, 2012; Migdisov and Williams-Jones, 2014; Migdisov and others, 2016). Indeed, REE were hitherto mined from magmatic sources such as carbonatites and pegmatites, or derivative sedimentary placer deposits (Linnen and others, 2014). However, hydrothermal origins are increasingly implicated for many ore deposits (Gieré, 1996). Hydrothermal REE deposit formation is often the working hypothesis for recent discoveries, not least because the distinction between hydrothermal and magmatic is not straightforward and hydrothermal overprinting is common in carbonatite-magmatic systems (Wall and Mariano, 1996; Weng and others, 2015).

An understanding of REE-bearing hydrothermal systems is still lacking. Although there has been progress in recent years, experimental studies have yet to cover all relevant $P-T-X_{\text {fluid }}$ conditions that prevail in these systems (Migdisov and others, 2016). Therefore, erroneous conclusions may be drawn, as deposits not easily interpreted as magmatic are considered hydrothermal by default. Even in the case where hydrothermal processes played an important role, their role may be overestimated because REE may only have been "... mobilised on the scale of metres and perhaps tens of metres ..." (Williams-Jones and others, 2012). This is common in many carbonatites and alkali intrusions, where magmatic processes were responsible for the initial concentration of the REE, and hydrothermal activity merely upgraded the deposit to economic grades (Wall and Mariano, 1996; Andrade and others, 1999; Walters and others, 2013; Wall, 2014; Feng and others, 2016; Trofanenko and others, 2016; Prokopyev and others, 2017). Hydrothermal activity in Nolans Bore redistributed the REE among various minerals on the centimeter scale (Schoneveld and others, 2015; Anenburg and others, 2018).

In this study, we experimentally evaluate the hydrothermal formation model by testing whether LREE are mobile in hydrothermal fluids saturated with fluorapatite, and whether decreasing pressure and temperature can deposit REE-rich fluorapatite (down to $400{ }^{\circ} \mathrm{C}$, for examle, Huston and others, 2016). We then test an alternative model in which Nolans Bore formed by reacting P, REE and Mg-rich carbonatite with silicate wall rocks, producing REE-fluorapatite as cumulate residue of carbonatite melt. Following the study of Biggar (1969), the magmatic experiments cover a temperature range of 650 to $900{ }^{\circ} \mathrm{C}$. We then generalize our results to identify a process forming skarn-like assemblages due to the carbonatite-melt-silicate-rock reaction, which we term "antiskarn".

\section{EXPERIMENTAL STRATEGY, MATERIALS AND METHODS}

Field relations show that Nolans-type deposits form by reaction between a mineralizing fluid or melt with silicate wall rock (fig. 1, Pandur and others, 2014; Schoneveld and others, 2015; Huston and others, 2016; Pandur and others, 2016). Therefore, two sets of experiments were conducted: one hydrothermal and a second, magmatic. A homogenous equilibrium assemblage was not sought in our experiments. Instead, layers of starting materials were placed in experimental capsules in order to observe reactions between the materials, in what are often referred to as "sandwich" experiments (see for example, Wallace and Green, 1988; Dasgupta and Hirschmann, 2007; Pistone and others, 2016; Gervasoni and others, 2017). Nolans-type deposits are LREE 

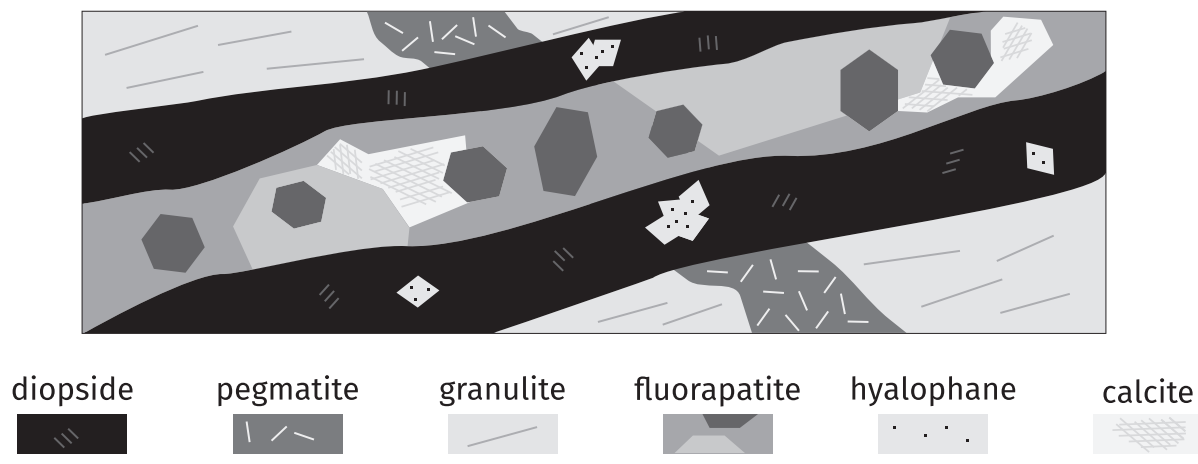

Fig 1. A schematic sketch of the likely form of primary mineralization in Nolans-type ore deposits. The scale of the vein width or its individual components can vary from a few centimeters to several meters.

deposits, therefore we used a single REE in each experiment: either $\operatorname{Pr}$ or $\mathrm{Nd}$. Praseodymium has the advantage of imparting a characteristic green color to minerals, allowing a quick and easy visual estimate of Pr transport in the capsule.

\section{Hydrothermal Experiments}

Hydrothermal experiments were run in a piston-cylinder apparatus using standard Teflon-talc-graphite-MgO assemblies in $19 \mathrm{~mm}$ pressure vessels (fig. 2). Temperature and pressure were controlled and monitored by a Eurotherm controller and in-house software. Although experiments in talc assemblies usually require pressure correction owing to high friction, we did not apply any pressure correction because (1) run durations were on the order of several days, allowing friction to dissipate, (2) the automated pressure control immediately compensated for any pressure loss due to friction dissipation, (3) the large Ag capsule (see below) expands with temperature, exerting pressure independently of the piston, and (4) pressures were often varied during the experimental runs and were arbitrarily chosen as a first approximation, therefore the improved accuracy given by friction correction was not deemed necessary.

The capsule materials used were cold-seal type Ag capsules as described by Hack and Mavrogenes (2006) (fig. 2). These capsules provide several advantages: (1) no hot welding is required, thus the volatile content of the starting materials $\left(\mathrm{H}_{2} \mathrm{O}\right.$ and $\left.\mathrm{CO}_{2}\right)$

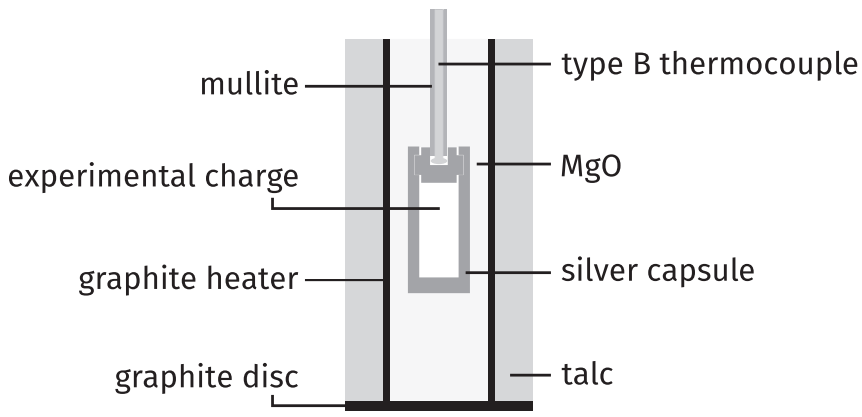

Fig. 2. Assembly design used in piston cylinder experiments running cold-seal Ag capsules. The capsule interior is $4 \mathrm{~mm}$ wide and $\sim 10 \mathrm{~mm}$ long. 
340 M. Anemburg and J. A. Mavrogenes—Carbonatitic versus hydrothermal origin for fluorapatite

TABLE 1

Synthetic compositions used for the piston cylinder runs. Units are weight percent

\begin{tabular}{lrrrrrrrrr}
\hline & Gran1 & Gran2 & Gran3 & NBC3 & NBC4 & NBC5 & NBC6 & NBC7 & NBC8 \\
\hline \hline $\mathrm{SiO}_{2}$ & 68.91 & 68.5 & 66.64 & & & & & & \\
$\mathrm{Al}_{2} \mathrm{O}_{3}$ & 15.99 & 16.8 & 15.97 & & & & & & \\
$\mathrm{Fe}_{2} \mathrm{O}_{3}$ & 6.21 & & & & & & & & \\
$\mathrm{FeO}$ & & 7.37 & 8.53 & & & & & & \\
$\mathrm{CaO}$ & 3.15 & 4.38 & 5.49 & 34.65 & 42.61 & 48.04 & 50.27 & 41.24 & 46.94 \\
$\mathrm{SrO}$ & & & & & & & 1.34 & 1.31 & \\
$\mathrm{MgO}$ & & & & 18.36 & 11.65 & 7.34 & 3.96 & 10.39 & 11.34 \\
$\mathrm{Na}_{2} \mathrm{O}$ & 2.36 & 2.95 & & & & & & & \\
$\mathrm{~K}_{2} \mathrm{O}$ & 3.38 & & 3.38 & & & & & & \\
$\mathrm{Pr}_{6} \mathrm{O}_{11}$ & & & & & & 3.00 & 3.50 & 5.50 & 3.50 \\
$\mathrm{Nd}_{2} \mathrm{O}_{3}$ & & & & 2.50 & 3.00 & & & & \\
$\mathrm{ThO}_{2}$ & & & & & & 0.50 & 1.00 & 1.00 & \\
$\mathrm{H}_{2} \mathrm{O}$ & & & & 4.48 & 4.79 & 4.92 & 4.79 & 4.04 & 9.29 \\
$\mathrm{CO}_{2}$ & & & & 29.79 & 28.74 & 28.01 & 27.02 & 29.98 & 21.22 \\
$\mathrm{CaF}_{2}$ & & & & 3.23 & 3.07 & 2.09 & 2.06 & 1.80 & 2.01 \\
$\mathrm{P}_{2} \mathrm{O}_{5}$ & & & & 7.00 & 6.14 & 6.11 & 6.05 & 4.74 & 5.70 \\
\hline
\end{tabular}

is precisely known, (2) the large internal capsule volume allows simulation of a more complex hydrothermal system, and (3) the thick capsule walls minimize the internal thermal gradient.

Several silicate mix compositions were prepared by mixing dried oxides $\left(\mathrm{SiO}_{2}\right.$, $\mathrm{TiO}_{2}, \mathrm{Al}_{2} \mathrm{O}_{3}$, and $\left.\mathrm{Fe}_{2} \mathrm{O}_{3}\right)$ and carbonates $\left(\mathrm{CaCO}_{3}, \mathrm{Na}_{2} \mathrm{CO}_{3}\right.$ and $\left.\mathrm{K}_{2} \mathrm{CO}_{3}\right)$ in an agate mortar and pestle with acetone and then firing at $1000{ }^{\circ} \mathrm{C}$ to a dehydrated and decarbonated sintered material that was then ground to powder (table 1). This powder is composed of quartz, feldspars, hematite and other aluminosilicates and closely represents an oxidized and anhydrous variant of the most common granulites hosting the Nolans Bore veins. The silicate-granulite ("Gran1") mix compositions were placed in each capsule along with $\mathrm{MgO}$ or $\mathrm{MgCO}_{3}$, "fluorapatite" (stoichiometric mix of $\mathrm{Ca}_{3}\left(\mathrm{PO}_{4}\right)_{2}$ and $\left.\mathrm{CaF}_{2}\right), \mathrm{Pr}_{6} \mathrm{O}_{11}$ or $\mathrm{Nd}_{2} \mathrm{O}_{3}, \mathrm{ThO}_{2}, \mathrm{CaCO}_{3}$ and $\mathrm{SrCO}_{3}$ as detailed in figure $3 \mathrm{~A}$. Oxygen fugacity $\left(\mathrm{fO}_{2}\right)$ was buffered by adding Re metal powder to each capsule. As the starting materials are oxidized, some of the Re was oxidized during each run to $\mathrm{ReO}_{2}$, buffering $\mathrm{fO}_{2}$ to the $\mathrm{Re}-\mathrm{ReO}_{2}$ buffer. This buffer was chosen because Nolans Bore contains sulfates, which require $f \mathrm{O}_{2}>\mathrm{Ni}-\mathrm{NiO}$, and iron is present as both $\mathrm{Fe}^{2+}$ and $\mathrm{Fe}^{3+}$ in allanite, suggesting $f \mathrm{O}_{2}<\mathrm{Fe}_{2} \mathrm{O}_{3}-\mathrm{Fe}_{3} \mathrm{O}_{4}$. The $\mathrm{Re}-\mathrm{ReO}_{2}$ buffer is conveniently located between these two buffers and is inert with respect to the capsule and starting materials. Two kinds of fluids were used in the runs. An acidic fluid consisting of $1 \mathrm{M} \mathrm{HCl}$ and 20 weight percent $\mathrm{NaCl}$, and a basic fluid prepared by neutralizing and saturating the acidic fluid with $\mathrm{CaCO}_{3}$. Details of all hydrothermal experiments are given in table 2 and figure 3.

Temperature control was accurate to within $2{ }^{\circ} \mathrm{C}$, except several transient excursions lasting several seconds in which the accuracy was within 10 to $15^{\circ} \mathrm{C}$. Pressure was accurate to within $\sim 0.05 \mathrm{kbar}$. After each experiment, the capsule was pierced with a 1 $\mathrm{mm}$ drill, to see if fluid bubbled from the capsule indicating fluid had remained for the duration of the run. The open capsule was rinsed with deionized water, filled with epoxy, and cut in half. Both halves were then mounted in epoxy and prepared as described below. 
REE-Th deposits: Experimental study of REE transport and crustal "antiskarn" metasomatism 341

A

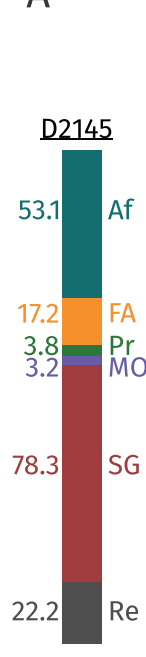

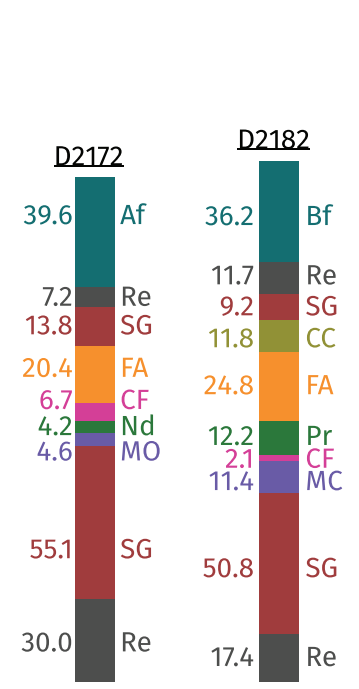

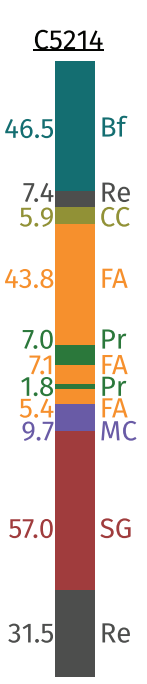

SG: silicate granulite

Re: rhenium metal Pr: $\mathrm{Pr}_{6} \mathrm{O}_{11}$ TO: $\mathrm{ThO}_{2}$ $\mathrm{Nd}: \mathrm{Nd}_{2} \mathrm{O}_{3}$

FA: fluorapatite

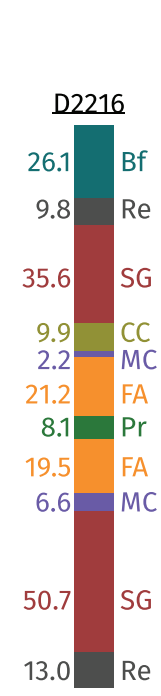

MO: MgO

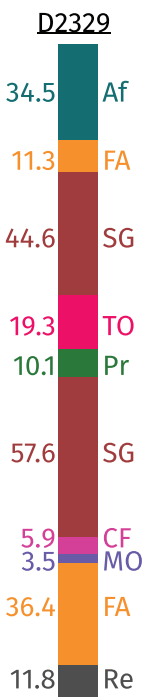

MC: $\mathrm{MgCO}_{3}$

CC: $\mathrm{CaCO}_{3}$

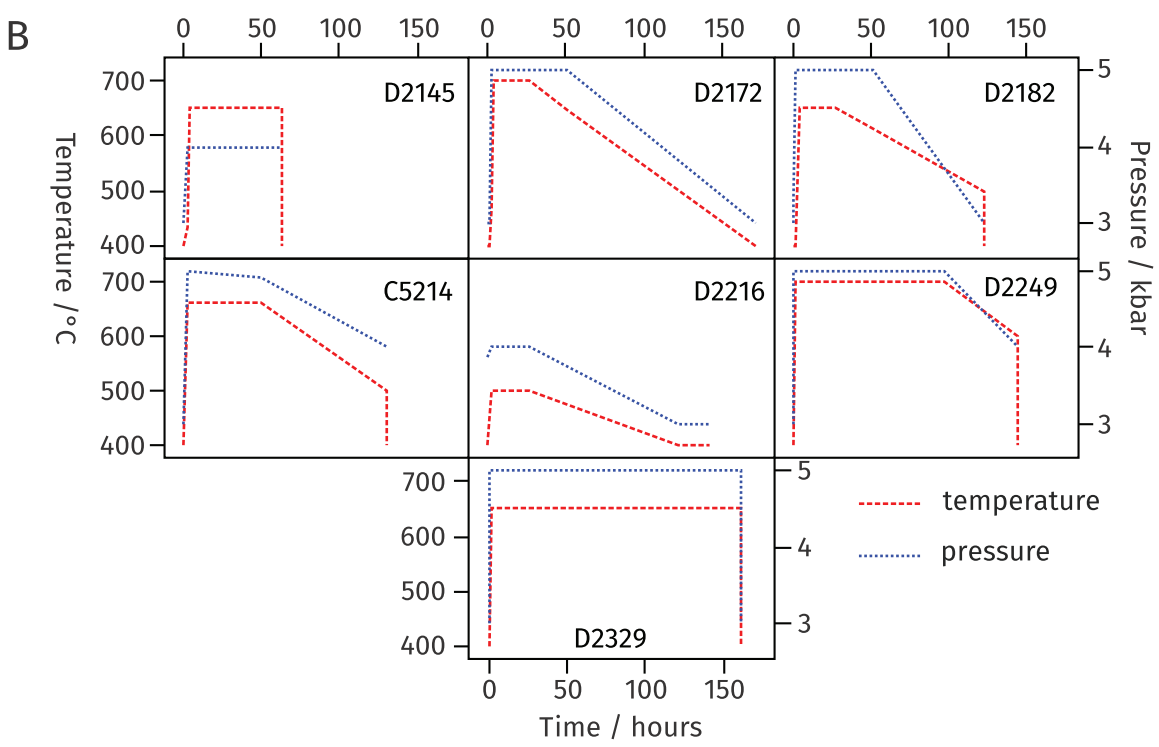

Fig. 3. (A) Starting materials for hydrothermal runs. (B) Graphical representation of pressuretemperature paths for each hydrothermal run.

\section{Magmatic Experiments}

Magmatic experiments were run in a similar fashion as the hydrothermal runs described above, with several differences. Some experiments were run in noble metal tubes, crimped and arc-welded. Capsules were filled with two layers: carbonatite on the bottom followed by silicate on top. Oxygen fugacity in the oxidized "Gran1" composition runs was buffered by placing Re metal in the bottom of the capsule. Runs 
TABLE 2

Run conditions and summary of resulting phases for each hydrothermal experiment

\begin{tabular}{|c|c|c|c|c|}
\hline Run & $\mathrm{T}\left({ }^{\circ} \mathrm{C}\right)$ & $\mathrm{P}$ (kbar) & Fluid & Phases \\
\hline D2145 & $\begin{array}{c}60 \mathrm{hr} \text { at } \\
650\end{array}$ & $60 \mathrm{hr}$ at 4 & Acidic & $\begin{array}{l}\text { actinolite, allanite, biotite, britholite, fluorapatite, } \\
\text { monazite, talc }\end{array}$ \\
\hline D2172 & $\begin{array}{c}24 \mathrm{hr} \text { at } \\
700,144 \mathrm{hr} \\
\text { to } 400\end{array}$ & $\begin{array}{c}48 \mathrm{hr} \text { at } 5 \\
120 \mathrm{hr} \text { to } 2.5\end{array}$ & Acidic & $\begin{array}{l}\text { actinolite, allanite, biotite, britholite, clinopyroxene, } \\
\text { fluorapatite, fluorite, norbergite }\end{array}$ \\
\hline D2182 & $\begin{array}{c}24 \mathrm{hr} \text { at } \\
650,96 \mathrm{hr} \\
\text { to } 500\end{array}$ & $\begin{array}{c}48 \mathrm{hr} \text { at } 5,72 \\
\text { hr to } 3\end{array}$ & Basic & $\begin{array}{l}\text { allanite, biotite, britholite, calcite, cerite, fluorapatite, } \\
\text { norbergite }\end{array}$ \\
\hline C5214 & $\begin{array}{c}48 \mathrm{hr} \text { at } \\
660,80 \mathrm{hr} \\
\text { to } 500\end{array}$ & $\begin{array}{l}48 \mathrm{hr} \text { at } 5,80 \\
\text { hr to } 4\end{array}$ & Basic & $\begin{array}{l}\text { actinolite, allanite, biotite, britholite, cerite, } \\
\text { clinopyroxene, fluorapatite, monazite }\end{array}$ \\
\hline D2216 & $\begin{array}{c}24 \mathrm{hr} \text { at } \\
500,96 \mathrm{hr} \\
\text { to } 400,20 \\
\text { hr at } 400\end{array}$ & $\begin{array}{l}24 \mathrm{hr} \text { at } 4,96 \\
\mathrm{hr} \text { to } 3,20 \mathrm{hr} \\
\text { at } 3\end{array}$ & Basic & $\begin{array}{l}\text { allanite, biotite, calcite, cerite, fluorapatite, monazite, } \\
\text { Pr-carbonate, talc }\end{array}$ \\
\hline D2249 & $\begin{array}{c}96 \mathrm{hr} \text { at } \\
700,48 \mathrm{hr} \\
\text { to } 600\end{array}$ & $\begin{array}{c}96 \mathrm{hr} \text { at } 5,48 \\
\mathrm{hr} \text { to } 4\end{array}$ & Acidic & $\begin{array}{l}\text { allanite, britholite/cerite, calcite, chondrodite, } \\
\text { clinopyroxene, fenghuangite, fluorapatite, fluorite, } \\
\text { huttonite, monazite, thorianite }\end{array}$ \\
\hline D2329 & $\begin{array}{l}160 \mathrm{hr} \text { at } \\
650\end{array}$ & $160 \mathrm{hr}$ at 5 & Acidic & $\begin{array}{l}\text { actinolite, allanite, biotite, britholite/cerite, } \\
\text { clinopyroxene, huttonite, Mg-hydroxyfluoride, } \\
\text { fluorapatite, fluorite, norbergite, Pr-oxychloride, Pr- } \\
\text { (hydro)oxyfluoride, thorianite }\end{array}$ \\
\hline
\end{tabular}

Phases in italics occur only in trace amounts.

employing the reduced "Gran2" and "Gran3" compositions were not buffered. These compositions contain $\mathrm{Fe}^{2+}$ added in the form of fayalite, synthesized by reducing a mixture of silica and hematite in a 1 atm furnace. Carbonatite starting mixes contained varying $\mathrm{Mg}$ contents in order to constrain carbonatite composition that would result in diopside, and to explore the expected phase assemblage outside of this range. All experiments were run at constant pressure and temperature, and quenched at the end. The magmatic experiment did not suffer from the transient temperature spikes experienced during the hydrothermal runs, thus temperature was known to within $2{ }^{\circ} \mathrm{C}$ throughout each run. Details of magmatic experiments are given in table 3 .

ANALYTICAL METHODS

Experimental charges were embedded in epoxy and polished with diamond paste to $1 / 4 \mu \mathrm{m}$ grit. Samples were then studied using a Hitachi S- $4300 \mathrm{SE} / \mathrm{N}$ field emission scanning electron microscope (FE-SEM). Chemical analyses were performed using an Oxford Instruments INCA X-MAX energy dispersive spectroscopy (EDS) system, employing an $80 \mathrm{~mm}^{2}$ silicon drift detector (SDD) and calibrated using various synthetic and natural reference materials. Beam conditions were $15 \mathrm{kV}$ accelerating voltage and $0.6 \mathrm{nA}$ beam current measured on a Faraday cup. As each experiment contained only a single REE (either Pr or Nd), there were no interferences in the EDS spectra and the method is considered sufficient (see for example, Reed and Ware, 1975; Ware, 1991; Robinson and others, 1998). Most analyses should be considered as semi-quantitative, due to the small size of the resulting phases-commonly smaller than $5 \mu \mathrm{m}$ across. Therefore, the data are of poor quality and are not reported here, apart from specific chemical compositions relevant to the discussion. 
REE-Th deposits: Experimental study of REE transport and crustal "antiskarn" metasomatism 343

TABLE 3

Run conditions for each magmatic experiment

\begin{tabular}{|c|c|c|c|c|c|c|}
\hline$\overline{\text { Run }}$ & $\mathrm{T}\left({ }^{\circ} \mathrm{C}\right)$ & $\mathrm{P}$ (kbar) & $\begin{array}{c}\text { Duration } \\
\text { (hours) }\end{array}$ & Capsule & Carbonatite (mg) & Silicate $(\mathrm{mg})$ \\
\hline$\overline{\mathrm{D} 2161}$ & 900 & 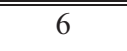 & 68 & $\overline{\mathrm{AuPd}}$ & NBC3 & Gran1 \\
\hline D2178 & 900 & 6 & 68 & $\mathrm{Ag}$ & NBC4 & Gran1 \\
\hline D2194 & 800 & 6 & 86 & $\mathrm{Ag}$ & NBC4 (73.7) & Gran1 (98.6) \\
\hline D2222 & 800 & 6 & 87 & $\mathrm{Ag}$ & NBC5 (89.0) & Gran1 (66.6) \\
\hline D2250 & 800 & 6 & 42 & $\mathrm{Ag}$ & NBC6 (106.9) & Gran1 (67.7) \\
\hline D2277 & 800 & 6 & 48 & $\mathrm{Ag}$ & NBC6 $(\sim 50)$ & Gran1 $(\sim 110)$ \\
\hline D2294 & 750 & 6 & 30 & $\mathrm{Ag}$ & $\operatorname{NBC6}(60.5) *$ & Gran2 (132.5) \\
\hline C5290 & 800 & 6 & 70 & $\mathrm{Ag}$ & NBC7 (71.6) & Gran2 (145.6) \\
\hline C5296 & 700 & 6 & 96 & $\mathrm{Ag}$ & NBC7 (93.0) & Gran2 (92.1) \\
\hline D2319 & 650 & 6 & 96 & $\mathrm{Ag}$ & NBC7 $(84.9) \dagger$ & Gran2 (95.9) \\
\hline D2332 & 650 & 6 & 65 & $\mathrm{AgPd}$ & NBC8 (19.2) & Gran3 (10.4) \\
\hline D2346 & 800 & 6 & 68 & $\mathrm{AgPd}$ & NBC8 (43.0) & Gran3 (40.6) \\
\hline D2594 & 750 & 6 & 72 & $\mathrm{AgPd}$ & $\begin{array}{c}47 \% \mathrm{NBC} 5+48 \% \mathrm{NBC} 7+5 \% \\
\mathrm{BaCO}_{3}(42.0)\end{array}$ & Gran3 (26.9) \\
\hline C5571 & 730 & 6 & 69 & $\mathrm{AgPd}$ & $\begin{array}{c}48 \% \mathrm{NBC} 5+47 \% \mathrm{NBC} 7+5 \% \\
\mathrm{Na}_{2} \mathrm{CO}_{3}(32.7)\end{array}$ & Gran3 (29.3) \\
\hline
\end{tabular}

* Also $9.4 \mathrm{mg}$ of $\mathrm{H}_{2} \mathrm{O}$.

${ }^{\dagger}$ Also $15.4 \mathrm{mg}$ of $\mathrm{AgC}_{2} \mathrm{O}_{4}$.

RESULTS

In this work, the terms "diopside" and "hedenbergite" are loosely applied to any clinopyroxene richer in $\mathrm{Mg}$ or $\mathrm{Fe}$, respectively. We use "britholite" to refer to end-member britholite or close compositions, "REE-fluorapatite" to refer to fluorapatite with appreciable $\operatorname{Pr}$ or $\mathrm{Nd}$ contents $(>\sim 1 \mathrm{wt} \%$, but far from end-member britholite), and "fluorapatite" to refer to REE-poor fluorapatite, in which $\mathrm{Pr}$ or $\mathrm{Nd}$ contents are at or below detection by EDS $(\leq \sim 0.5 \mathrm{wt} \%)$.

\section{Hydrothermal Experiments}

In all runs, the silicate starting material recrystallized to an assemblage of quartz, amphibole, epidote, feldspars, magnetite, and other minerals too small to analyze. Occasional halite and sylvite cubes were found on the polished surface of the samples, which most likely formed by opening trapped fluid cavities during polishing and subsequent evaporation during carbon coating. The results described below only address the interfaces between layers. Although Pr used in the starting materials was oxidized $\left(\mathrm{Pr}_{6} \mathrm{O}_{11}\right.$, a mixed oxide: $\left.4 \mathrm{Pr}^{4+} \mathrm{O}_{2} \cdot \operatorname{Pr}^{3+}{ }_{2} \mathrm{O}_{3}\right)$, it completely reduced to $\operatorname{Pr}^{3+}$ during the runs, as evident by the bright green color of the resulting Pr-bearing phases (in contrast to dark brown to black $\mathrm{Pr}^{4+}$-bearing phases) and by the lack of any Pr in the $\mathrm{Th}^{4+}$-bearing phases: huttonite and thorianite. A summary of resulting phases in each run is given in table 4 .

Run D2145.- The interface between silicate and $\mathrm{MgO}$ consists of actinolite on the silicate side, and biotite on the $\mathrm{MgO}$ side. Small allanite prisms (up to $20 \mu \mathrm{m}$ wide) and actinolite needles (up to $50 \mu \mathrm{m}$ long) occur in the biotite matrix. The $\operatorname{Pr}_{6} \mathrm{O}_{11}$ layer recrystallized to monazite crystals up to $10 \mu \mathrm{m}$ wide, with talc filling the space between 
TABLE 4

Description of resulting phases in the hydrothermal runs and their characteristics

\begin{tabular}{|c|c|c|}
\hline Phase & Approximate formula & Comments \\
\hline Actinolite & $(\mathrm{Ca})_{2}(\mathrm{Mg}, \mathrm{Fe})_{5} \mathrm{Si}_{8} \mathrm{O}_{22}(\mathrm{OH})_{2}$ & $\begin{array}{l}\text { May contain up to } 1 \% \mathrm{Na}_{2} \mathrm{O} \text { and } \mathrm{K}_{2} \mathrm{O} \text {, and } \\
\text { up to } 5 \% \mathrm{Al}_{2} \mathrm{O}_{3} \text {. }\end{array}$ \\
\hline Allanite & $(\mathrm{Pr}, \mathrm{Ca})_{2}(\mathrm{Al}, \mathrm{Fe})_{3}\left(\mathrm{SiO}_{4}\right)_{3}(\mathrm{OH}) * \dagger$ & $\begin{array}{l}\text { Occurs as elongated prisms, occasionally } \\
\text { several crystals splay from a single point. } \\
\text { Commonly zoned. }\end{array}$ \\
\hline Biotite & $\mathrm{K}(\mathrm{Mg}, \mathrm{Fe})_{3} \mathrm{AlSi}_{3} \mathrm{O}_{10}(\mathrm{OH}, \mathrm{F})_{2}$ & $\begin{array}{l}\text { Commonly F-rich. Occurs as anhedral } \\
\text { masses that transform into well-formed } \\
\text { sheeted crystals in open cavities. }\end{array}$ \\
\hline Britholite & $(\mathrm{Pr}, \mathrm{Ca})_{5}\left([\mathrm{Si}, \mathrm{P}] \mathrm{O}_{4}\right)_{3}(\mathrm{~F}, \mathrm{OH}, \mathrm{Cl}) * \dagger$ & $\begin{array}{l}\text { Occur as individual sub-hexagonal crystals, } \\
\text { commonly zoned, or as overgrowths around } \\
\text { fluorapatite. May be non-stoichiometric, } \\
\text { having more Pr and less Ca than end- } \\
\text { member britholite: } \\
\mathrm{Pr}_{3} \mathrm{Ca}_{2}\left(\mathrm{SiO}_{4}\right)_{3}(\mathrm{~F}, \mathrm{OH}, \mathrm{Cl}) \text {. See comment for } \\
\text { cerite for additional details. }\end{array}$ \\
\hline Calcite & $\mathrm{CaCO}_{3} \uparrow$ & $\begin{array}{l}\text { May contain minor Mg. Mostly occurs as } \\
\text { euhedral crystals. }\end{array}$ \\
\hline Cerite & $(\mathrm{Pr}, \mathrm{Ca})_{9}(\mathrm{Mg}, \mathrm{Fe})\left(\mathrm{SiO}_{4}\right)_{3}\left(\mathrm{HSiO}_{4}\right)_{4}(\mathrm{OH}, \mathrm{F}, \mathrm{Cl})_{3}$ & $\begin{array}{l}\text { Forms sub-cubic prisms when well formed. } \\
\text { In some cases, cerite is P-bearing and Fe- } \\
\text { and Ca-poor, making it compositionally } \\
\text { very similar to Ca-poor and Pr-rich } \\
\text { britholite. Our resulting phases were not } \\
\text { available for X-ray diffraction analysis, and } \\
\text { identification by Raman is not possible as } \\
\text { the two reference spectra for cerite and } \\
\text { britholite from the RRUFF database } \\
\text { (Downs, 2006)-IDs R060708 and R070412, } \\
\text { respectively-are almost identical. Therefore, } \\
\text { distinction between the two is possible only } \\
\text { when the composition is unequivocal or the } \\
\text { crystal habit is unambiguous. These } \\
\text { difficulties are also known from natural } \\
\text { cerite, britholite and "unnamed mineral E" } \\
\text { found in Bastnäs, Sweden (Holtstam and } \\
\text { Andersson, 2007). }\end{array}$ \\
\hline Chondrodite & $(\mathrm{Mg}, \mathrm{Fe})_{5}\left(\mathrm{SiO}_{4}\right)_{2}(\mathrm{~F}, \mathrm{OH})_{2}$ & $\begin{array}{l}\text { A humite-group mineral. Occurs as anhedral } \\
\text { porous masses. }\end{array}$ \\
\hline Clinopyroxene & $\mathrm{Ca}(\mathrm{Mg}, \mathrm{Fe}) \mathrm{Si}_{2} \mathrm{O}_{6} \dagger$ & $\begin{array}{l}\text { Occurs as anhedral masses, octagonal } \\
\text { prisms or elongated needle-like crystals. } \\
\text { Occasionally zoned. Contains up to } 1 \% \\
\mathrm{Na}_{2} \mathrm{O} \text { and } 5 \% \mathrm{Al}_{2} \mathrm{O}_{3} \text {. Some } \mathrm{Fe} \text { is present as } \\
\mathrm{Fe}^{3+} \text {, evident by low analytical totals. The } \\
\text { most likely substitution mechanism is } \mathrm{Fe}^{2+}+ \\
\mathrm{Si}^{4+}=\mathrm{Fe}^{3+}+\mathrm{Al}^{3+} \text {. }\end{array}$ \\
\hline
\end{tabular}

crystals. The contact between the $\operatorname{Pr}_{6} \mathrm{O}_{11}$ and fluorapatite layers is mostly sharp, with monazite crystals in direct contact with fluorapatite grains just several $\mu \mathrm{m}$ wide. Locally, allanite crystals grew from the monazite layer into the fluorapatite layer, 
TABLE 4

(continued)

\begin{tabular}{|c|c|c|}
\hline Phase & Approximate formula & Comments \\
\hline Fenghuangite & $(\mathrm{Th}, \mathrm{Ca}, \mathrm{Sr}, \mathrm{Pr})_{5}\left([\mathrm{Si}, \mathrm{P}] \mathrm{O}_{4}\right)_{3}(\mathrm{~F}, \mathrm{OH})$ & $\begin{array}{l}\text { A Th-rich analogue of britholite. May or } \\
\text { may not contain Pr. Forms coarse anhedral } \\
\text { crystals. }\end{array}$ \\
\hline Fluorapatite & $\mathrm{Ca}_{5}\left(\mathrm{PO}_{4}\right)_{3}(\mathrm{~F}, \mathrm{OH}, \mathrm{Cl}) \dagger$ & $\begin{array}{l}\text { Occurs as fine } \mu \mathrm{m} \text {-scale anhedral crystals. } \\
\text { May contain small amounts of } \mathrm{Si} \text { and } \mathrm{Na} \text {, } \\
\text { even when no } \mathrm{Pr} \text { is detected. }\end{array}$ \\
\hline Fluorite & $\mathrm{CaF}_{2}$ & Occurs as coarse subhedral crystals. \\
\hline Huttonite & $\mathrm{ThSiO}_{4}$ & $\begin{array}{l}\text { Occurs as anhedral overgrowths around } \\
\text { thorianite. May contain up to } 1.5 \% \mathrm{CaO} \text {. }\end{array}$ \\
\hline $\begin{array}{l}\text { Mg- } \\
\text { hydroxyfluoride }\end{array}$ & $\mathrm{Mg}(\mathrm{OH}) \mathrm{F}$ & Occurs as coarse subhedral crystals. \\
\hline Monazite & $\mathrm{PrPO}_{4}$ & $\begin{array}{l}\text { Occurs as porous anhedral crystals. May } \\
\text { contain } 1 \% \text { to } 3 \% \text { of } \mathrm{CaO} \text { and } \mathrm{SiO}_{2} \text {. }\end{array}$ \\
\hline Norbergite & $\mathrm{Mg}_{3}\left(\mathrm{SiO}_{4}\right)_{3}(\mathrm{~F}, \mathrm{OH})_{2}$ & $\begin{array}{l}\text { Humite-group mineral. Occurs as irregular } \\
\text { crystals or overgrowths around biotite. }\end{array}$ \\
\hline $\begin{array}{l}\text { Pr- } \\
\text { (hydro)oxyfluoride }\end{array}$ & Pr-O-F-(H?) & $\begin{array}{l}\text { Contains excess } \mathrm{O} \text { and } \mathrm{F} \text { over Pr, and } \\
\text { together with low totals suggesting presence } \\
\text { of } \mathrm{H}^{+} \text {. However, compositions are not } \\
\text { consistent and we were unable to derive a } \\
\text { formula. Occurs as subhedral crystals, } \\
\text { commonly with inclusions of a similar } \\
\text { phase with different ratios of } \mathrm{Pr}, \mathrm{O} \text { and } \mathrm{F} \text {. }\end{array}$ \\
\hline Pr-carbonate & $\operatorname{Pr}_{2}\left(\mathrm{CO}_{3}\right)_{3}$ & $\begin{array}{l}\text { Occurs as a porous aggregate of small } \\
\text { tabular crystals. Composition inferred based } \\
\text { on low totals that match } \operatorname{Pr}_{2}\left(\mathrm{CO}_{3}\right)_{3} \text {. }\end{array}$ \\
\hline Pr-oxychloride & $\mathrm{PrOCl}$ & $\begin{array}{l}\text { Occurs as elongated prims with two } \\
\text { excellent cleavage planes at right angles. }\end{array}$ \\
\hline Talc & $\mathrm{Mg}_{3} \mathrm{Si}_{4} \mathrm{O}_{10}(\mathrm{OH}, \mathrm{F})_{2}$ & $\begin{array}{l}\text { Contains up to } 1 \% \text { F. Occurs as irregular } \\
\text { sheets, possibly a polishing artifact. }\end{array}$ \\
\hline Thorianite & $\mathrm{ThO}_{2}$ & $\begin{array}{l}\text { Occurs in the cores of other Th-bearing } \\
\text { minerals, anhedral. May contain up to } 3 \% \\
\mathrm{SiO}_{2} \text { and } 0.5 \% \mathrm{CaO} \text {. }\end{array}$ \\
\hline
\end{tabular}

* Allanite and britholite in run D2172 consist of Nd instead of Pr.

${ }^{\dagger}$ Has SrO substituting for $\mathrm{CaO}$ in run D2249.

enclosing pre-existing fluorapatites in a poikilitic manner. Uncommon aggregates of REE-fluorapatite needles 5 to $10 \mu \mathrm{m}$ long occur at the monazite-fluorapatite interface, and some fluorapatite grains-immediately adjacent to monazite-have thin $(<1$ 


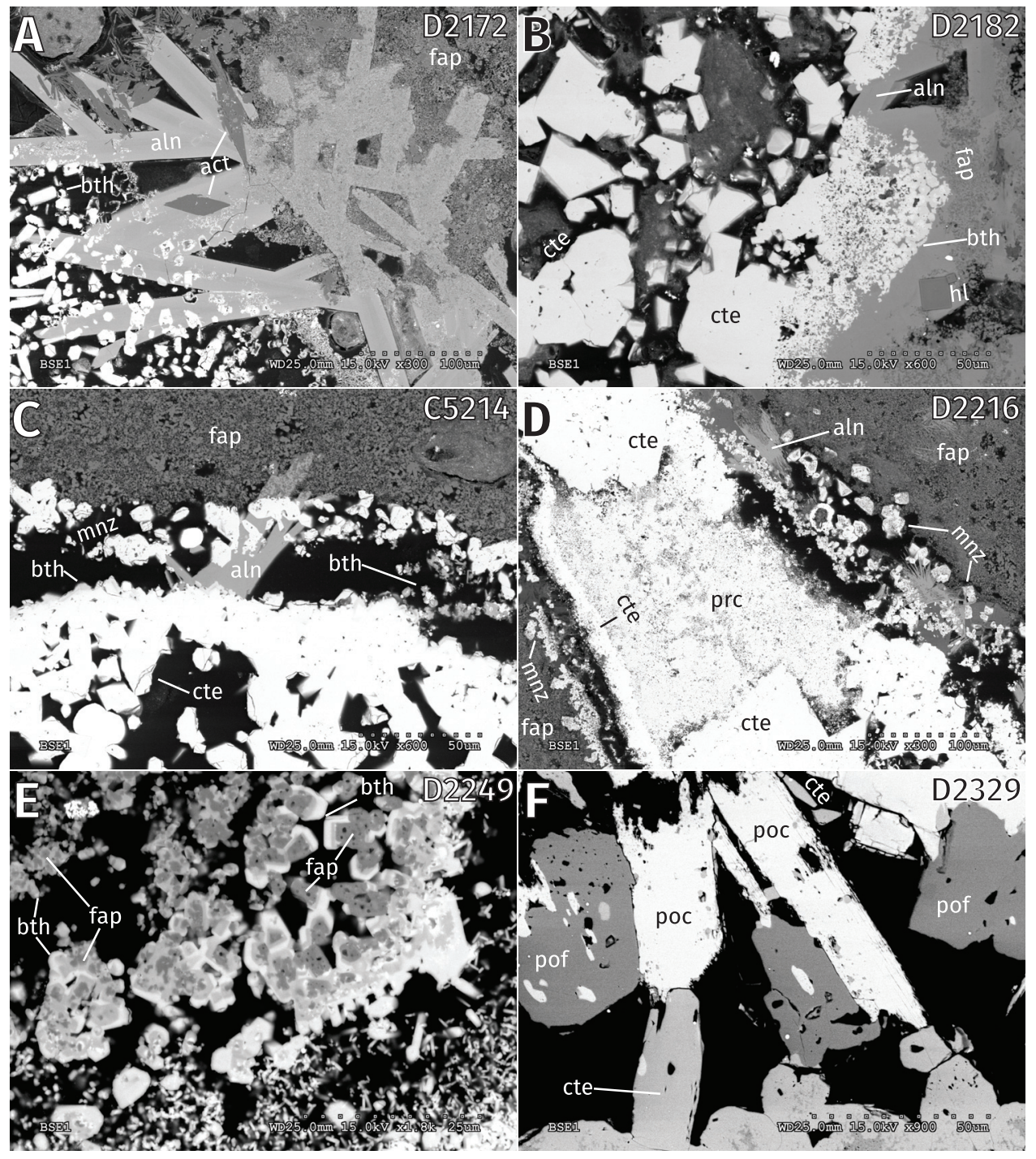

Fig. 4. Back-scattered images of hydrothermal runs. (A) Run D2172, (B) Run D2182, (C) Run C5214, (D) Run D2216, (E) Run D2249, (F) Run D2329. Scale bars are divided to 1/10 sections of the annotated length.

$\mu \mathrm{m})$ britholite overgrowths. The overwhelming majority of fluorapatite in the experimental charge is unremarkable and contains no Pr.

Run D2172.-The interface between silicate and $\mathrm{MgO}$ consists of a $20 \mu \mathrm{m}$ wide layer of clinopyroxene followed by a wide zone of norbergite. The $\mathrm{Nd}_{2} \mathrm{O}_{3}$ layer recrystallized to hexagonal prisms of britholite up to $30 \mu \mathrm{m}$ across, set in a matrix of biotite. Spectacular elongated allanite crystals (often longer than $100 \mu \mathrm{m}$ ) commonly nucleate on top of the Nd layer and grew towards the silicate layer, trapping inclusions of britholite, fluorite, actinolite, rare clinopyroxene, and fluorapatite that occur in the $\mathrm{Nd}_{2} \mathrm{O}_{3}-\mathrm{CaF}_{2}-$ silicate transition zone (fig. 4A). The fluorapatite layer is unremarkable and contains no Nd-enriched zones. 


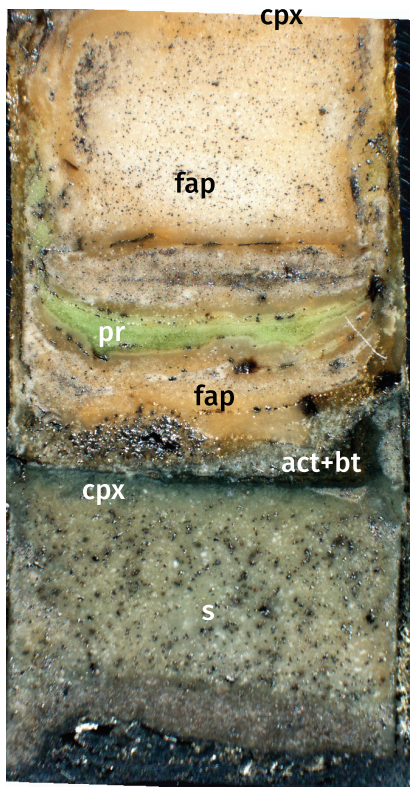

A. $\mathrm{C5214}$

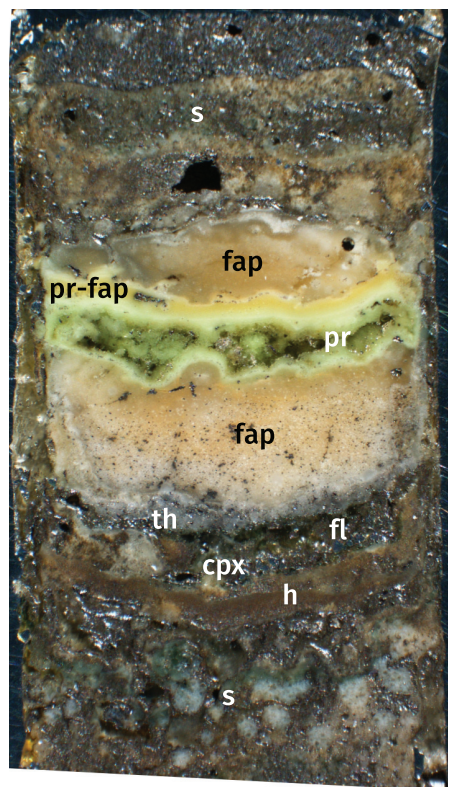

B. D2249

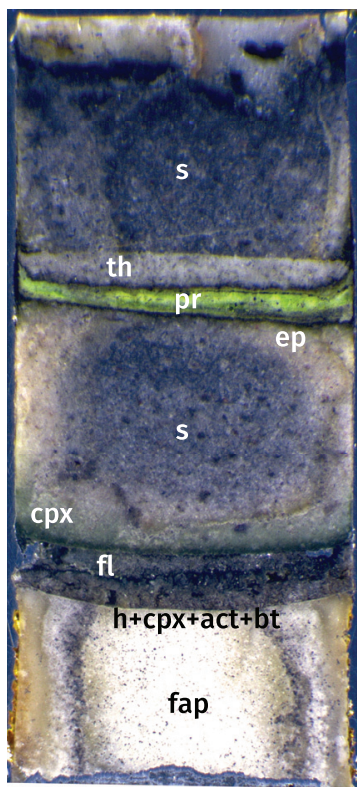

C. D2329

Fig. 5. Reflected light photomicrographs of polished sections of runs (A) C5214, (B) D2249 and (C) D2329. Width of each section is about $4 \mathrm{~mm}$.

Run D2182. - The mineral sequence from the silicate to the $\mathrm{MgCO}_{3}$ and the $\mathrm{CaF}_{2}$ layers is clinopyroxene, small tabular allanite crystals embedded in massive biotite, euhedral calcite, and anhedral norbergite. The $\operatorname{Pr}_{6} \mathrm{O}_{11}$ layer recrystallized to euhedral cerite up to $50 \mu \mathrm{m}$ wide. At the $\operatorname{Pr}_{6} \mathrm{O}_{11}$-fluorapatite interface, cerite grains are much finer $(<10 \mu \mathrm{m})$, with some of the smallest grains surrounded by britholite overgrowths, both of which are mostly trapped as inclusions in coarse allanite $(>50 \mu \mathrm{m})$ nucleated on cerite and grown into the fluorapatite layer (fig. 4B). The fluorapatite is fine grained and contains no Pr, even when next to cerite-britholite or when included in allanite.

Run C5214 (fig. 5A).- The silicate- $\mathrm{MgCO}_{3}$ interface consists of clinopyroxene followed by actinolite hosted in biotite matrix. All carbonate dissolved during the run, resulting in a large cavity filled with loosely dispersed biotite crystals. Fluorapatite remained unchanged while the interlayered $\operatorname{Pr}_{6} \mathrm{O}_{11}$ layers recrystallized to subhedral cerite, with occasional britholite overgrowths near the fluorapatite layers. Monazite at interfaces with allanite (up to $100 \mu \mathrm{m}$ long) grown from the interface towards fluorapatite, trapping both monazite and fluorapatite as inclusions (fig. 4C). The $\mathrm{CaCO}_{3}$ in the top of the capsule was completely dissolved during the run, and large $(\sim 200 \mu \mathrm{m})$ elongated crystals of clinopyroxene grew in the resulting cavity. No other carbonate phases were observed elsewhere in the capsule, suggesting complete dissolution into the fluid.

Run D2216. - Both $\mathrm{MgCO}_{3}$ layers recrystallized to massive biotite, irregular talc, and euhedral calcite. Figure $4 \mathrm{D}$ shows a $\operatorname{Pr}_{6} \mathrm{O}_{11}$ layer recrystallized to porous blocky cerite (several 10s of $\mu \mathrm{m}$ wide) with zones of Pr-carbonate aggregates. The interface between $\operatorname{Pr}_{6} \mathrm{O}_{11}$ and fluorapatite consists of fine-grained cerite on the $\operatorname{Pr}_{6} \mathrm{O}_{11}$ side and monazite on the fluorapatite side. Both phases host abundant fluorapatite inclusions. Allanite splays (up to $50 \mu \mathrm{m}$ long) occasionally occur next to monazite, trapping abundant fluorapatite as inclusions. No fluorapatite in this run contains detectable Pr. 


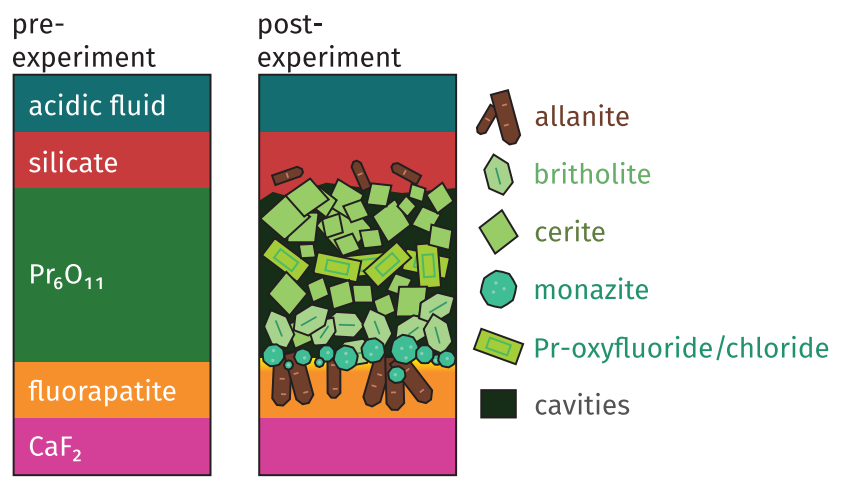

Fig. 6. A sketch combining and summarizing several features observed in hydrothermal runs. Note yellow fluorapatite, signifying incorporation of REE as fluorapatite-britholite solid solution.

Run D2249 (fig. 5B).-Fluorapatite throughout the capsule contains at least 3.5 percent $\mathrm{SrO}$. Most fluorapatite grains are homogenous but others are zoned with the rims containing $>10$ percent $\mathrm{SrO}$. Most of the $\mathrm{CaF}_{2}$ dissolved, leaving a cavity with several remnant fluorite crystals up to $20 \mu \mathrm{m}$ wide. Rare Sr-bearing calcite occurs with fluorite, which is surprising since the fluid in this run was acidic. The silicate-MgO interface consists of Sr-free clinopyroxene and chondrodite. The $\mathrm{SrCO}_{3}$ layer dissolved completely, leaving a large cavity in which euhedral crystals of Sr-bearing (1-2\% SrO), Fe-rich clinopyroxene crystals formed. The $\mathrm{ThO}_{2}$ layer recrystallized to huttonite with embayed thorianite cores. Fenghuangite appears at the contact of this layer and the fluorapatite layer. Some rare $\operatorname{Pr}$ is observed in fenghuangite. The $\operatorname{Pr}_{6} \mathrm{O}_{11}$ recrystallized to elongated hexagonal britholite up to $50 \mu \mathrm{m}$ long. While most crystals are close to end-member britholite, many of them have rims with a higher $\mathrm{Ca} / \mathrm{Pr}$ ratio (that is, containing some REE-fluorapatite component). The $\operatorname{Pr}_{6} \mathrm{O}_{11}$-fluorapatite interface is poorly defined. Figure $4 \mathrm{E}$ shows fluorapatite crystals adjacent to the original $\operatorname{Pr}_{6} \mathrm{O}_{11}$ layer partially recrystallized to REE-fluorapatite, commonly with euhedral Pr-rich (approaching britholite) overgrowths, forming some of the largest fluorapatite crystals seen in our experiments $(15-20 \mu \mathrm{m})$. The grain size and Pr-content of the crystals decreases with distance from the $\operatorname{Pr}_{6} \mathrm{O}_{11}$ layer, until no $\mathrm{Pr}$ is detectable in fluorapatite 200 to $250 \mu \mathrm{m}$ away (yellow "pr-fap" in fig. 5B). Rare allanite crystals occur in this zone.

Run D2329 (fig. 5C). - Fluorapatite in this run contains no detectable Pr, regardless of location in the capsule. The MgO layer recrystallized to large $(100 \mu \mathrm{m})$ crystals of Mg-hydroxyfluoride, surrounded by norbergite, biotite, and clinopyroxene, respectively. Occasional actinolite crystals nucleated on the biotite layer and grew outward. The $\mathrm{CaF}_{2}$ layer consists of fluorite and euhedral clinopyroxene, commonly up to 50 $\mu \mathrm{m}$ long. Clinopyroxene is also abundant at the $\mathrm{CaF}_{2}$-silicate interface and its abundance decreases through the silicate layer. Fine-grained britholite occurs in the silicate- $\operatorname{Pr}_{6} \mathrm{O}_{11}$ interface, with abundant allanite-cored epidote in the silicate side of the interface, and cerite in the $\operatorname{Pr}_{6} \mathrm{O}_{11}$ side. The interior of the $\operatorname{Pr}_{6} \mathrm{O}_{11}$ layer is composed of large euhedral crystals of Pr-(hydro) oxyfluoride and Pr-oxychloride 50 to $100 \mu \mathrm{m}$ long (fig. 4F). The $\operatorname{Pr}_{6} \mathrm{O}_{11}-\mathrm{ThO}_{2}$ interface mirrors that of $\operatorname{Pr}_{6} \mathrm{O}_{11}$-silicate, and consists of coarse cerite and fine-grained britholite. The $\mathrm{ThO}_{2}$ layer consists of 10 to 20 $\mu \mathrm{m}$ large subhedral huttonite with thorianite cores.

The main REE recrystallization features observed in these runs are shown in figure 6. The REE oxide recrystallized to phosphates (monazite and P-bearing britholite) when in direct contact with a P-bearing layer-fluorapatite in our case. Phosphorus is 
rarely found outside of this zone. Given an acidic fluid, high temperatures (650-700 ${ }^{\circ} \mathrm{C}$ ), and time (several days at least), REE migrates to the fluorapatite layer in a contact-metasomatic reaction. Allanite grows out from the REE-oxide layer, regardless of what it is growing into. This suggests high mobility of $\mathrm{Ca}, \mathrm{Al}, \mathrm{Fe}$ and $\mathrm{Si}$. Most of the REE layer will recrystallize to cerite or P-free britholite, with the heart of the layer recrystallizing to REE fluorides or chlorides, suggesting these compounds are extremely insoluble and grew metastably even though $\mathrm{Ca}$ and $\mathrm{Si}$ (the main components of cerite or britholite) are present in the fluid.

\section{Magmatic Experiments}

All magmatic experiments except for run D2178 had carbonate and silicate layers on the bottom and top of the capsule, respectively. In general, the silicate starting mix melted or recrystallized to an assemblage of glass (in high $T$ runs), quartz (in low $T$ runs), plagioclase, clinopyroxene, and magnetite. Fayalite, occasionally mantled by magnetite or hedenbergite, was observed in $\mathrm{Fe}^{2+}$-bearing runs. The carbonatite layers show features consistent with melting, but as carbonate liquids do not quench to glass it is not straightforward interpreting the resultant textures. Chemical equilibrium was not attained. Many crystals are zoned or vary compositionally with capsule position. For example, clinopyroxenes are Mg-rich (diopside) in contact with Mg-bearing carbonatite and Fe-rich (hedenbergite) in the Fe-bearing silicate layer. In contrast to the abundance of REE phases in the hydrothermal runs (cerite, britholite, monazite, allanite, et cetera), magmatic runs of $\geq 700{ }^{\circ} \mathrm{C}$ contain only fluorapatite with varying amounts of REE, and REE-bearing vesuvianite. End-member britholite does not occur in these runs. Fluorapatite REE contents vary between runs and within a single run, and REE contents will be described qualitatively as REE-poor or REE-rich.

Run D2161. - This experiment resulted in three parts: bottom, middle and upper. The bottom is composed of calcite crystals (up to $40 \mu \mathrm{m}$ wide) with interstitial fine-grained fluorapatite (bottom of fig. 7A). Fluorapatite contains no $\mathrm{Nd}$ in the bottom of the capsule, but gradually becomes Nd-bearing towards the contact with the middle part, evident by the gradient of back-scattered electron brightness. The middle part is composed of a calcite layer with sub-spherical calcite blebs that appear to rise into the silicate layer (middle of fig. 7B). The top part is composed of silicate glass, quartz, plagioclase, hedenbergite, magnetite and a fine-grained phase suspected to be amphibole. The contact between the calcite blebs and the silicates is dominated by diopside with a thin rim of hedenbergite on the silicate side (fig. 7B). The calcite blebs contain abundant zoned fluorapatite with Nd-rich rims, and occasional forsterite. At the contact with diopside, fluorapatite is completely Nd-rich, with occasional clintonite occurring next to it. The calcite blebs also contain vugs (fig. 7A).

Run D2178. - In this run, the carbonate layer was placed on top of the silicate layer. The resulting texture is similar to Run D2161, in reverse. That is, the silicate is on the bottom, and the coarse-grained calcite with interstitial fluorapatite is on the top. The reaction zone consists of diopside on the silicate side, occasionally with hedenbergitic cores (particularly next to the silicate layer), and $\mathrm{Nd}$-rich fluorapatite, rounded calcite, spinel and occasional clintonite plates on the carbonatite side (fig. 7C). The fine-grained interstitial fluorapatite does not show variable $\mathrm{Nd}$ contents across the capsule, in contrast to run D2161.

Run D2194.-This run is similar to run D2161. The bottom consists of calcite and fine-grained interstitial fluorapatite with increasing $\mathrm{Nd}$ contents upwards. The silicate on the top consists of glass, magnetite and silicates. The contact zone consists of a thick layer of calcite, Nd-rich fluorapatite and chondrodite (bottom of fig. 7D). The top of this layer protrudes into the silicate above it. The contact consists of hedenbergite on the silicate side and diopside on the carbonatite side (top left of fig. 7D). Spinel, 


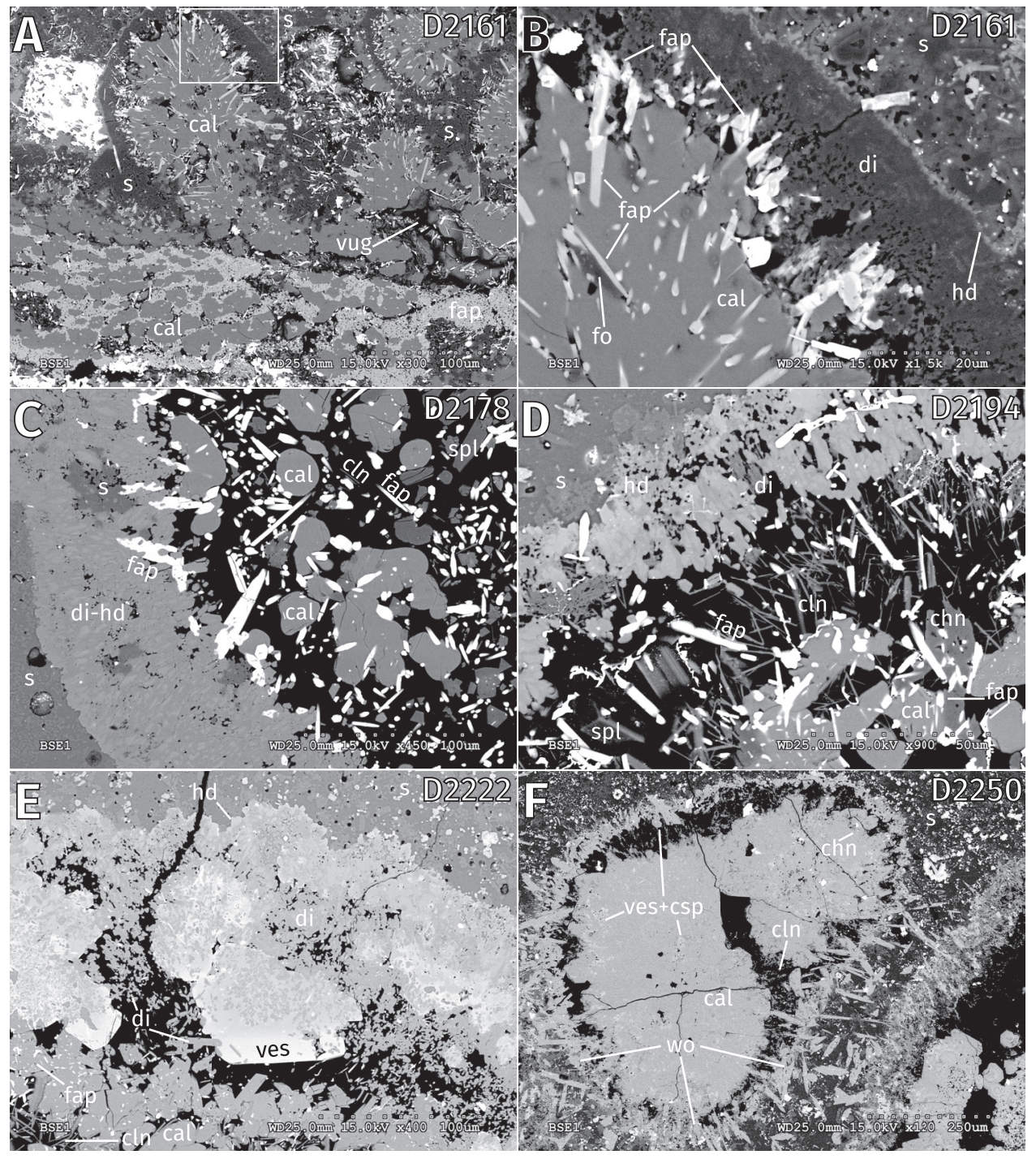

Fig. 7. Back-scattered images of magmatic runs. White patches are capsule material trapped in cavities during polishing. Occasional dendritic white streaks are potassium perrhenate $\left(\mathrm{KReO}_{4}\right)$ crystallized on top of the polished surface by low-temperature reaction of Re-oxides with K present in the run. (A, B) Run D2161, (C) Run D2178, (D) Run D2194, (E) Run D2222, (F) Run D2250, (G) Run D2277, (H) Run D2294, (I) Run C5296, (J) Run D2319, (K) Run D2332, (L, M) D2346, (N, O) D2594, (P) C5571. Rectangle in (A) and $(\mathrm{N})$ outlines the approximate positions of figures $7 \mathrm{~A}$ and $7 \mathrm{O}$, respectively. Scale bars are divided to $1 / 10$ sections of the annotated length.

coarser Nd-rich fluorapatite and clintonite occur between the clinopyroxenes and the carbonatite (center of fig. 7D).

Run D2222.-As above, the bottom consists of calcite and fine-grained fluorapatite with increasing Pr contents upwards. The contact zone consists of blebs protruding into the silicate with calcite, Pr-rich fluorapatite and chondrodite (bottom of fig. 7E). The interface between the blebs and the silicate consists of clintonite, diopside, 

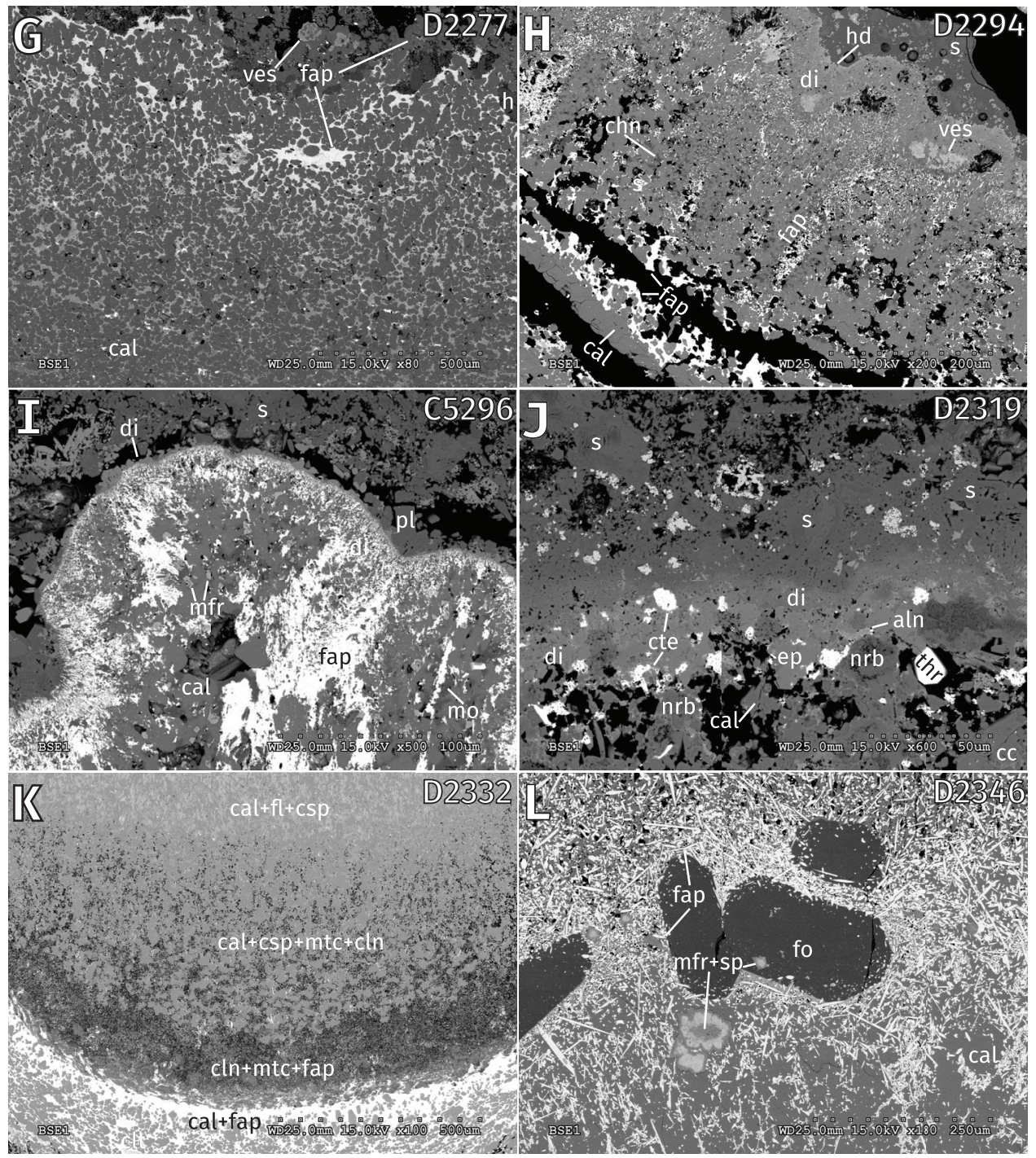

Fig. 7. (continued).

hedenbergite and vesuvianite (middle to top of fig. 7E). The vesuvianite is commonly zoned, with Pr-rich zones closer to the carbonatite.

Run D2250 (fig. 8A).- The bottom of this capsule is similar to previous runs except that calcite cores are Sr-free and rims are Sr-bearing, and fluorapatite contains Th. However, the contact zone is fundamentally different to previous runs (fig. 7F). The bulk of the blebs are composed of calcite with dispersed chondrodite, and the carbonatite-silicate interface composed of clintonite, vesuvianite, cuspidine and minor diopside. Large wollastonite crystals grew from the interface into the silicate.

Run D2277. - This run is similar to run D2250, with the main difference being the presence of small amounts of fluorapatite at the base of the carbonatite blebs (fig. 7G).

Run D2294. - The bottom contains the usual calcite and fine grained fluorapatite. The contact zone consists of sub-vertical arrays of Pr-rich fluorapatite in a matrix of 

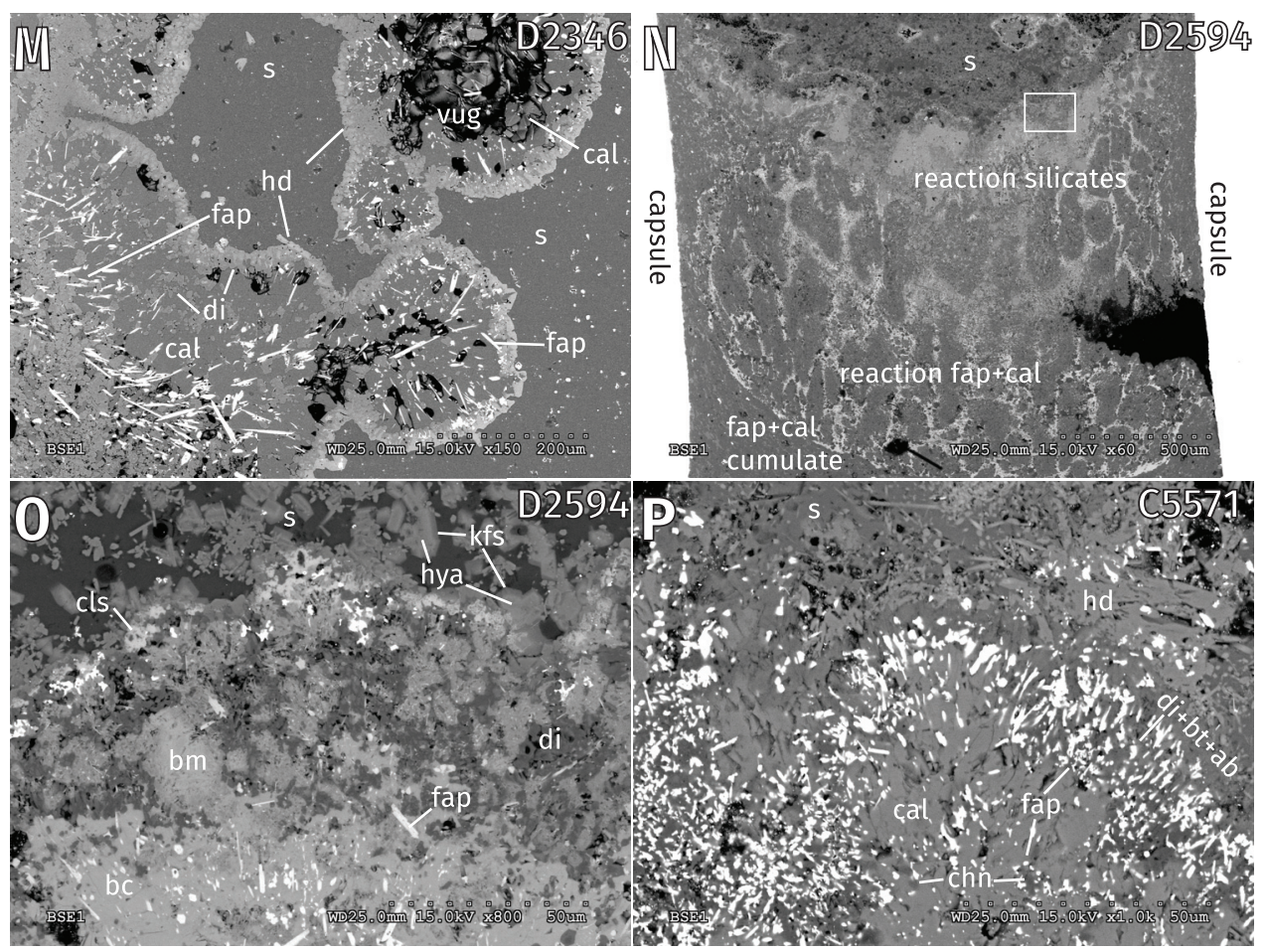

Fig. 7. (continued).

calcite and chondrodite (fig. $7 \mathrm{H}$ ). The carbonatite-silicate interface is composed of diopside and hedenbergite (on the carbonatite and silicate sides, respectively), vesuvianite and a fine-grained $\mathrm{Ca}-\mathrm{Mg}-\mathrm{Al}-\mathrm{Si}$ phase, most likely clintonite (top of fig. $7 \mathrm{H}$ ). There are abundant gas cavities throughout the contact zone.

Run C5290 (fig. 8B).- The textures obtained in this run are essentially identical to run D2294, apart from vesuvianite, that is not present here, and higher Pr contents of fluorapatite.

Run C5296 (fig. 8C).-Again, calcite and fine grained fluorapatite at the capsule bottom, with monazite, thorianite and MgOHF. Praseodymium contents of fluorapatite increase upwards towards the contact zone. The contact zone consists of calcite blebs with vertical arrays of fluorapatite-britholite, similar to runs D2294 and C5290. The calcite blebs contain minor MgOHF, magnesioferrite and spinel (fig. 7I). The carbonatite-silicate interface consists of a thin layer of diopside $(<10 \mu \mathrm{m})$, with plagioclase growing from the interface towards the silicate (top of fig. 7I).

Run D2319. - The bottom contains a mixture of fine-grained calcite, monazite, fluorapatite, thorianite and cerite. The modal cerite/monazite ratio increases upwards. Fluorapatite does not contain REE detectable by EDS. The reaction zone is thin $(50-70 \mu \mathrm{m})$ and contains calcite, thorianite, cerite, diopside, plagioclase, norbergite and epidote occasionally zoned to allanite (fig. 7J).

Run D2332 (fig. 8D).- - Unlike the previous runs which have three distinct zones (bottom carbonatite, contact carbonatite and silicate), this run has several zones (see fig. $7 \mathrm{~K})$. The bottom zone contains calcite, magnesite, fluorapatite and monazite. The lower green zone consists of calcite and Pr-rich fluorapatite. The yellow zone consists of calcite, clintonite, monticellite, cuspidine, magnesioferrite, fluorite and rare Pr-rich 


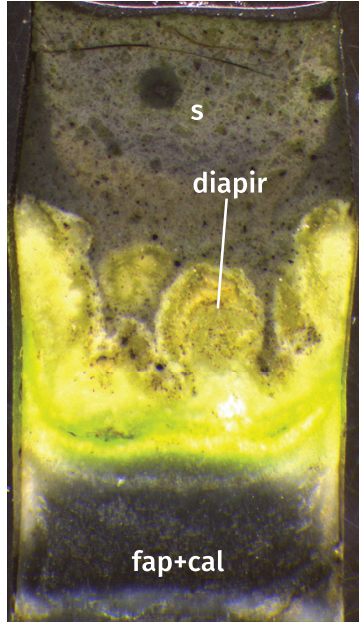

A. D2250

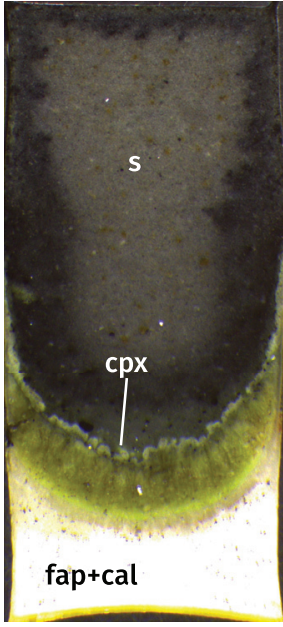

B. $\mathrm{C} 5290$

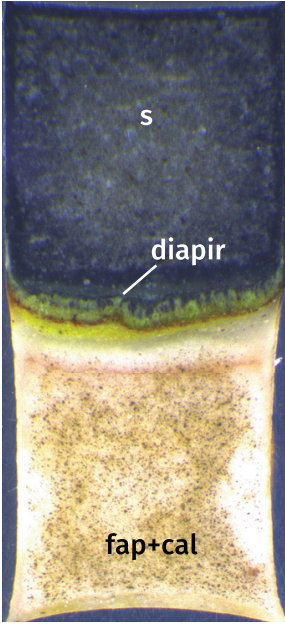

C. $\mathrm{C} 5296$

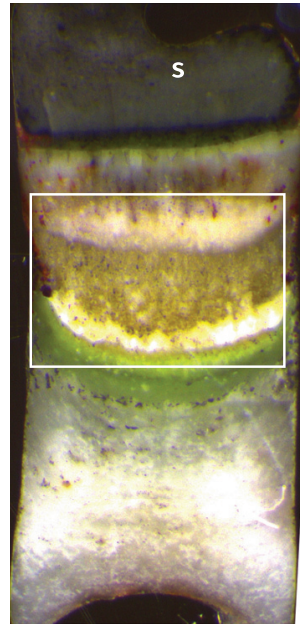

D. D2332

Fig. 8. Reflected light photomicrographs of polished sections of runs (A) D2250, (B) C5290, (C) C5296 and (D) D2332. Width of each section is about $4 \mathrm{~mm}$. Rectangle in (D) outlines approximate position of figure $7 \mathrm{~K}$.

fluorapatite. Fluorite and cuspidine dominate towards the top of this zone. The upper green zone consists of potassic ferrorichterite. No clinopyroxenes were observed in this run.

Run D2346.- The bottom zone consists of calcite with abundant fluorapatite needles, becoming Pr-rich upwards with occasional Pr-poor cores. This zone also contains large forsterite crystals up to $200 \mu \mathrm{m}$ long and zoned spinel-magnesioferrite crystals, some of which are included in forsterite (fig. 7L). The contact zone contains cavity-bearing blebs that appear to have risen up through the sides of the capsule around the silicate (fig. 7M). These blebs are composed of calcite, diopside and Pr-rich fluorapatite. The carbonatite-silicate interface consists of diopside on the carbonatite side and hedenbergite on the silicate side.

Run D2594. - The overall texture is similar to run D2294. The blebs in the top of the contact zone contain barytocalcite, calcite, platy aggregates of barian F-biotite, Pr-rich fluorapatite needles, celsian, and rare grandite (fig. $7 \mathrm{~N}$ ). The carbonatitesilicate interface consists of diopside-hedenbergite as above, and hyalophane zoned to Ba-free K-feldspar (fig. 7O). No phases containing $\mathrm{Ba}$ as a major or minor element occur in the bottom, below the reaction zone.

Run C5571.- The blebs consist of calcite, chondrodite, Pr-rich fluorapatite (occasionally zoned to britholite), and irregular holes suggesting sodium carbonates that were lost during sample preparation. The carbonatite-silicate interface is a fine intergrowth of abundant Pr-rich fluorapatite, F-biotite, diopside, and rare albite (fig. $7 \mathrm{P})$. The interface is rimmed by hedenbergite on the silicate side. $\mathrm{Na}_{2} \mathrm{O}$ contents of diopside are 0.5 to 1.5 percent.

DISCUSSION OF EXPERIMENTS

\section{Ruling Out Hydrothermal Origin}

Our hydrothermal experiments demonstrate that REE and Th are exceptionally immobile in the chemical system hypothesized for the hydrothermal Nolans Bore 
model. As the host rocks for the Nolans Bore deposit do not contain significant amounts of REE, P or F (the essential components for the britholite-fluorapatite series), these elements had to be transported together. Britholite was observed in all runs except D2216, the lowest temperature run $\left(500{ }^{\circ} \mathrm{C}\right)$, suggesting britholite is a high-temperature phase and a hypothetical fluorapatite-britholite solvus occurs around $600^{\circ} \mathrm{C}$. This suggests a higher temperature of formation than estimated by Huston and others (2016) for Nolans Bore $\left(400-450{ }^{\circ} \mathrm{C}\right.$ ) and by Pandur and others (2014) for Hoidas Lake $\left(<350^{\circ} \mathrm{C}\right)$, based on fluid inclusion analyses. This provides evidence that the fluid inclusions in these deposits record the later hydrothermal alteration stage (see for example, Schoneveld and others, 2015; Anenburg and others, 2018). Although britholite is stable at higher temperatures, it must be demonstrated that REE, $\mathrm{Th}, \mathrm{P}$ and $\mathrm{F}$ are mobile. Unfortunately, this is not the case and it appears that the REE and $\mathrm{Th}$ are the least mobile elements in our runs. A common feature is that $\operatorname{Pr}_{6} \mathrm{O}_{11}$, $\mathrm{Nd}_{2} \mathrm{O}_{3}$ and $\mathrm{ThO}_{2}$ react with the components in immediately adjacent layers (figs. 4B and $4 \mathrm{C}$ ). This stands in stark contrast to the mobility of other elements in the experiment ( $\mathrm{Ca}, \mathrm{Sr}, \mathrm{Si}, \mathrm{Al}, \mathrm{Mg}, \mathrm{Fe}, \mathrm{F}, \mathrm{Cl}, \mathrm{K}$ and $\mathrm{Na}$ ). Phases containing these elements as major components formed near where they were placed in the capsule (for example, humites at the Mg-F interface, or biotite and amphibole at the MgO layer). These elements also occur in phases elsewhere in the capsule where they were not immediately available. For example, cerite contains $\mathrm{Mg}$ and $\mathrm{Fe}$, allanite contains $\mathrm{Si}$, and $\mathrm{F}, \mathrm{Cl}, \mathrm{Al}$, and $\mathrm{Sr}$ occur in phases throughout the capsule. In contrast and importantly, monazite occurs only at the Pr-P interface. End-member britholite occurs within the $\operatorname{Pr}_{6} \mathrm{O}_{11}$ layer and becomes P-bearing (that is, containing some fluorapatite component) only when it is in direct contact with pre-existing fluorapatite (fig. $4 \mathrm{E}$ ). Allanite mostly nucleates on the REE layers and grows outward. Perhaps most surprisingly, run D2329 contains Pr-oxychloride and Pr-(hydro) oxyfluoride at the $\operatorname{Pr}_{6} \mathrm{O}_{11}-$ $\mathrm{ThO}_{2}$ interface (fig. 4F), where it had neither adjacent $\mathrm{Si}$ nor $\mathrm{P}$ to react with, suggesting that $\operatorname{Pr}_{6} \mathrm{O}_{11}$ formed insoluble Pr-oxyhalides with the same ligands thought to make it mobile.

The observed REE phase assemblage is most likely metastable. Monazite can react with $\mathrm{SiO}_{2}$ and $\mathrm{CaF}_{2}$ to form britholite, or Pr-oxychloride and fluoride can react with monazite and $\mathrm{SiO}_{2}$ to form britholite as well. Pr-free fluorapatite, P-free britholite and intermediate compositions should not co-exist at constant pressure-temperature-fluidcomposition conditions. This is similar to the results obtained by Krenn and others (2012) at similar temperatures $\left(\geq 650{ }^{\circ} \mathrm{C}\right)$ showing that REE-bearing apatite is stable, whereas other phases (monazite and end-member fluorapatite) are not. Indeed, two runs (D2145 and D2249) showed a reaction in which fluorapatite is progressively enriched in the britholite component towards the $\operatorname{Pr}_{6} \mathrm{O}_{11}$ layer. These reaction zones only occurred at the Pr-P interface. The reaction zone in run D2145 was only several micrometers wide, while in run D2249 it was wider (fig. 4E), but this run was held at $700{ }^{\circ} \mathrm{C}$ for 4 days. Both were run with acidic fluid at high temperature $\left(>650{ }^{\circ} \mathrm{C}\right)$. All other runs, including high temperature runs with basic fluid did not produce Pr-rich overgrowths on fluorapatite. Run D2329, with acidic fluid, was held for almost a week at $650{ }^{\circ} \mathrm{C}$, but $\operatorname{Pr}_{6} \mathrm{O}_{11}$ was placed in contact with silicate, not phosphate. In this case, no reaction zone is seen, suggesting that the enrichment of $\mathrm{Pr}$ in fluorapatite is a contact dissolution-precipitation reaction assisted by acidic fluids. It may be argued that fluorapatite is unreactive and reaction kinetics are sluggish, but the presence of Sr-bearing fluorapatite in run D2249 requires addition of Sr from an external source. This indicates fluorapatite reacted with elements in the fluid. It was expected that lowering pressure and temperature during the runs would cause the formation of Pr-rich overgrowths around fluorapatite, but none were observed in any of the runs. Several experimental studies examined the effect of varied fluid compositions 
on apatite, monazite, allanite, and related phases (Harlov and others, 2002; Harlov and Förster, 2003; Harlov and others, 2003; Harlov and others, 2005; Harlov and others, 2007; Hetherington and others, 2010; Budzyń and others, 2011; Harlov and others, 2011; Mair and others, 2017). These studies reacted large natural crystals with fluids of varying compositions, a method useful to investigate reactions with preexisting crystals. However, it is commonly unclear whether a phase was unstable and partially dissolved due to incomplete reaction, or was stable and partially dissolved as an adjustment to new equilibrium conditions. Regardless of these complications, most studies show that reactions in these systems are extremely sluggish and new phases nucleate on previously existing phases in a dissolutionprecipitation process. In most cases, REE-rich phases such as monazite will nucleate on apatite, suggesting that the britholite substitution in apatite is not preferred at hydrothermal conditions. Significant mobilization of the REE to form REE-rich apatite was observed only with peralkaline fluids employing $\mathrm{Na}_{2} \mathrm{Si}_{2} \mathrm{O}_{5}$ (Budzyń and others, 2011; Krenn and others, 2012).

REE solubility is enhanced in low pH fluids (Migdisov and Williams-Jones, 2014; Migdisov and others, 2016), and neutralization of this acidic fluid was suggested by Huston and others (2016) as the depositional mechanism at Nolans Bore. However, neutralization of acidic fluids by reaction with wall rock would cause formation of hydrous phases such as biotite and amphibole, as seen in our experiments. However, no such phases are observed in Nolans Bore and the reaction zone consists of an anhydrous assemblage dominated by clinopyroxene.

Our experimental results agree with the recent results of Migdisov and WilliamsJones (2014) and Migdisov and others (2016) showing that F and P act to deposit REE rather than transport them. The presence of $\mathrm{Cl}$ in the fluid does not matter as the solubility is determined by the least soluble components (fluorides and phosphates). The low solubility of REE phosphates was also experimentally demonstrated by Zhou and others (2016). The observation of calcite and $\mathrm{CO}_{2}$ inclusions in apatite raises the possibility that $\mathrm{CO}_{3}^{2-}$ might be the complexing ligand for REE transport, but its effectiveness has yet to be demonstrated. Taken together with the presence of $\mathrm{F}$ but absence of REE fluorocarbonates, transport by carbonate-bearing hydrous fluids process seems unlikely. Furthermore, Ayers and Watson (1991) showed that $\mathrm{CO}_{2}$ in aqueous fluids reduces the solubility of fluorapatite, thereby immobilizing REE, making transport by carbonic species less likely.

Following the above the arguments, we conclude that Nolans Bore could not have formed by hydrothermal transport of REE in aqueous or aqueous-dominated fluids. The combination of REE, $\mathrm{P}$, and $\mathrm{F}$ is insoluble and it is not possible to transport them together from any source to the deposition site under geologically plausible conditions relevant to Nolans-type deposits. It is only possible by the action of extremely acidic or peralkaline fluids, both of which would react significantly with the Nolans Bore wall rocks to form features that are not observed, such as hydrous alteration zones or fenites, respectively.

\section{Experimental Evidence for Magmatic-Carbonatitic Origin}

Any textural interpretation of the magmatic experiments reported here must be made with caution, as carbonate melts do not quench to glass. There are several features common to most runs. First, in the lower parts of each capsule, rounded calcite is surrounded by fine-grained fluorapatite (for example fig. 7G). While resembling two immiscible liquids, this is most probably unlikely (also see discussion of carbonatite quench textures by Martin and others, 2013). For these to be the result of immiscibility, one of the phases must be pure liquid calcium carbonate that melts at temperatures well above our run conditions $\left(>1300{ }^{\circ} \mathrm{C}\right.$, Biggar, 1969). The second liquid would be close to fluorapatite composition, with a strong chemical gradient of 
increasing REE contents upwards. This too would have a melting point higher than achieved in our runs as indicated by single phase studies $\left(>1600^{\circ} \mathrm{C}\right.$, Bhatnagar, 1969) and ternary calcite-apatite- $\mathrm{H}_{2} \mathrm{O}$ mixtures which consist of calcite, apatite, melt and vapor at our experimental conditions (Biggar, 1969). Additionally, liquid carbonates and phosphates quench to intergrown dendritic and skeletal crystals, none of which are observed here. Instead of liquid immiscibility, we interpret the calcite+fluorapatite zone in the bottom of our capsule as crystal settling from the carbonatitic liquid. As our starting compositions did not correspond to pure liquids at experimental pressure and temperature, calcite and fluorapatite were both on the cotectic (see Biggar, 1969). Initially, the fluorapatite could not accommodate REE, but as the experiment progressed, two processes occurred. Firstly, loss of $\mathrm{H}_{2} \mathrm{O}$ from the liquid carbonatite to the melting silicate led to crystallization of the carbonatite along the fluorapatite-calcite cotectic. Secondly, carbonatite melt assimilated $\mathrm{SiO}_{2}$ from the silicate layer, which facilitated REE uptake by newly-crystallized fluorapatite via britholite-type substitution (see for example, Hammouda and others, 2010). Crystal settling of fluorapatite is particularly evident in run D2346, where crystals accumulated on top of large forsterite crystals (fig. 7L). Rounded calcite crystals in contact with carbonatite melts were observed in previous studies as well (Cooper and others, 1975; Weidendorfer and others, 2017). Wyllie and others (1962) and Biggar (1966) reported that apatite in equilibrium with liquid is usually equant whereas quench apatite is usually needle-like. Fluorapatite in our experiments is commonly elongated and rarely equant, indicative of quenching. However, we interpret the elongated crystal habit to result from chemical quenching rather than temperature drop, as suggested by Pistone and others (2016) for other experiments where two compositions with contrasting $\mathrm{H}_{2} \mathrm{O}$ contents reacted.

The second common feature is the existence of calcite-rich blebs protruding upwards into the silicate layer (figs. 7A, 7F, and 7M). These blebs are readily interpreted as diapirs: liquid carbonatite that rose into denser silicate magma (fig. 8A). Quench textures are absent from these blebs because of $\mathrm{H}_{2} \mathrm{O}$ loss and subsequent crystallization of the liquid. There are two main areas in the blebs: the silicatecarbonatite reaction selvages and the carbonate interiors. The composition of the reaction selvage is mostly controlled by the $\mathrm{CaO} / \mathrm{MgO}$ ratio of the carbonatite. All runs conducted at $\geq 700{ }^{\circ} \mathrm{C}$ contain minerals that correlate with this ratio (fig. 9), regardless of the carbonatite/silicate ratio of the starting mix or temperature. The selvage contains wollastonite, vesuvianite, diopside and forsterite in order of increasing $\mathrm{MgO}$ contents of the carbonatite. All runs contain an aluminous phase (either clintonite or spinel), most likely because of the $\mathrm{Al}_{2} \mathrm{O}_{3}$-rich composition of the silicate starting mix. Surprisingly, allanite is only observed in the low-temperature run $\left(650{ }^{\circ} \mathrm{C}\right.$, D2319), even though it is known to be stable to higher temperatures (Hermann, 2002). Allanite is ubiquitous in all Nolans-type deposits, and it may seem to be part of the primary magmatic mineral assemblage. However, our failure to synthesize allanite at magmatic temperatures taken together with the abundance of allanite in our hydrothermal runs suggests it to be a later hydrothermal overprint.

The resulting textures show striking similarities to Nolans-type deposits. The selvages in these rocks are essentially monomineralic diopside, a feature easily reproduced in our experiments, which constrains the $\mathrm{MgO} /(\mathrm{CaO}+\mathrm{MgO})$ ratio of the carbonatite to about 0.2 (fig. 9). It is not clear whether an aluminous phase existed in the natural selvages as they are universally altered, but it is possible that allanitecommonly occurring at the diopside-fluorapatite interface of the natural rocksreplaced any aluminous phases that may have formed during the carbonatite-silicate reaction. 


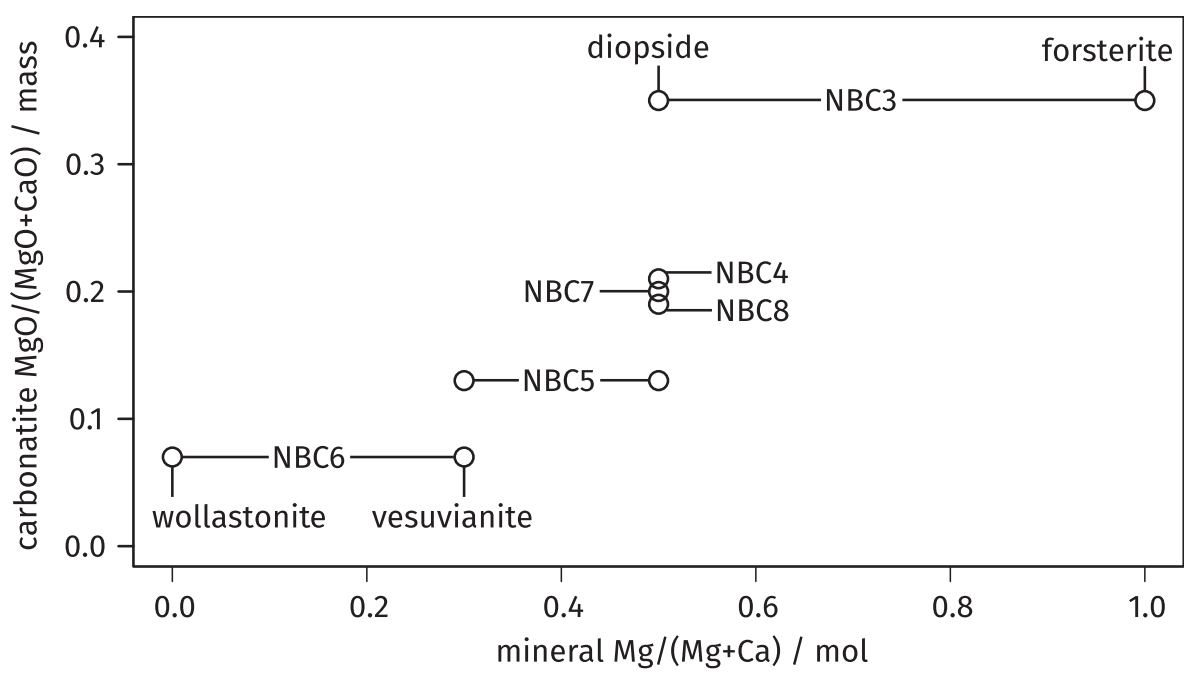

Fig. 9. Diagram showing the mineral phases that occur in the carbonatite-silicate interface as a function of the $\mathrm{Mg}$ contents of the carbonatite. The $\mathrm{CaO}$ value used in the calculation excludes $\mathrm{Ca}$ added in the form of $\mathrm{CaF}_{2}$. No Fe is assumed present for diopside and forsterite. The $\mathrm{Mg}$ and Ca contents of vesuvianite vary in our experiments, so a representative value of 0.3 was used.

Our runs contain volumetrically significant calcite in the blebs whereas igneous calcite is rare in Nolans-type deposits. This is likely because our experiments are closed systems, where the liquid carbonatite cannot exit the capsule. Calcite sequesters Ca and $\mathrm{CO}_{3}^{2-}$, whereas forsterite or humite-group minerals sequester $\mathrm{Mg}, \mathrm{F}$ and $\mathrm{H}_{2} \mathrm{O}$, with a contribution of $\mathrm{SiO}_{2}$ assimilated from the silicate (as suggested for the Barra do Itapirapuã carbonatite by Andrade and others, 1999). In a natural open system, the carbonatite flows through and reacts with the silicate wall rock according to the reaction:

$$
\begin{aligned}
& \mathrm{CaMg}\left(\mathrm{CO}_{3}\right)_{2}+2 \mathrm{SiO}_{2}=\mathrm{CaMgSi}_{2} \mathrm{O}_{6}+2 \mathrm{CO}_{2} . \\
& \text { in carbonatite in wall rock in selvage volatile gas }
\end{aligned}
$$

Magnesium solubility in carbonatites increases with pressure (Dasgupta and Hirschmann, 2007; Hammouda and Keshav, 2015). Apart from the conventional decarbonation process illustrated by equation (3) and widely known from skarns and marbles, this process could be further promoted by rising carbonatitic liquids undergoing decompression. Carbonatites in general are effective in dissolving $\mathrm{P}_{2} \mathrm{O}_{5}$ (Biggar, 1969; Wallace and Green, 1988; Baker and Wyllie, 1992; Ryabchikov and others, 1993; Klemme and Dalpé, 2003; Gorbachev and others, 2017). Calcic carbonatites can dissolve less fluorapatite than magnesian carbonatites (Hammouda and others, 2010), such that decreasing $\mathrm{Mg}$ contents decrease fluorapatite solubility promoting equation (3) wherever a continuous stream of carbonatite liquid occurs. The carbonatite also assimilates silica from the wall rock, allowing REE to enter the fluorapatite lattice via the britholite substitution. Rare monomineralic igneous calcite patches observed in Nolans-type deposits are probably not melt pockets: Lee and others (2000) show that even Mg-rich carbonatitic liquid precipitate calcite instead of dolomite. Therefore, the observed calcite in Nolans Bore crystallized along the carbonatite cotectic. The residual Mg-bearing carbonatitic liquid flowed away from the fluorapatite mineralization zone, to form a crystalline carbonatite elsewhere. Linnen and others (2014) write that carbonatites rich in $\mathrm{P}$ and $\mathrm{F}$ will crystallize abundant apatite, sequestering the REE 
early. Fractionated carbonatites will then have little REE left (Bühn and others, 2001; $\mathrm{Xu}$ and others, 2010; Zaitsev and others, 2014; Xu and others, 2015). Nolans-type deposits can be seen as the extreme case of that process, trapping REE in the cumulate fluorapatite and depleting the residual carbonatite of any economic contents of REE. Fractionation of apatite (together with calcite and clinopyroxene) is invoked in a recent model for Na-carbonatite genesis (Weidendorfer and others, 2017).

The $\mathrm{BaCO}_{3}$-bearing experiment (D2594) demonstrated the efficiency in which carbonatites mobilize Ba. The initial carbonatite mix contained 20 times more $\mathrm{CaCO}_{3}$ than $\mathrm{BaCO}_{3}$ on a molar basis, and additional $\mathrm{Ca}$ in the phosphate, fluoride, and hydroxide components. Yet, at the conclusion of the run, the cumulate assemblage at the bottom of the capsule contained no Ba-bearing phases, concentrating it into the residual liquid immediately below the contact zone. The liquid lost abundant Ba by reaction with the silicate, evident by the presence of celsian, hyalophane and Ba-micas. Nonetheless, the residual liquid crystallized to barytocalcite, suggesting the final $\mathrm{CaCO}_{3} / \mathrm{BaCO}_{3}$ ratio in the melt was close to unity (consistent with the large solubility of $\mathrm{Ba}$ in carbonatites reported by Jones and Wyllie, 1983). In natural systems unconstrained by our closed capsule, the Ba contents of the carbonatite will likely be buffered by continuous reaction with silicate rocks to form hyalophane and will never reach such extreme concentrations. Furthermore, carbonatites also contain sulfur that will exsolve along with $\mathrm{Ba}$ in aqueous fluids following solidification, depositing insoluble barite rather than barytocalcite. Nonetheless, the abundance of Ba-rich silicates that exclusively formed at the reaction zone was unexpected.

An additional run was conducted with 5 percent $\mathrm{Na}_{2} \mathrm{CO}_{3}$ in the carbonatite to test the effect of alkalis on the silicate-carbonatite reaction (C5571). The Na remained largely dissolved in the carbonatite and did not react extensively with the silicate. The clinopyroxenes remained Na-poor (that is, negligible aegirine component), and only limited formation of albite was observed. The silicate glass contained only $\sim 1.5$ percent $\mathrm{Na}_{2} \mathrm{O}$ adjacent to the reaction zone, suggesting it contributed very little to flux-melting the silicate as it partitions heavily into the carbonatite liquid. Run C5571 was conducted at a relatively low temperature $\left(730{ }^{\circ} \mathrm{C}\right)$ and we suspect that at higher temperatures the albite would not be stable, thus eliminating any modal evidence for the presence of $\mathrm{Na}$ in the carbonatite. Essentially, $\mathrm{Na}$ remains in the carbonatite and does not participate in the metasomatic reaction until it reaches shallower levels (see discussion about fenitization below).

Rao (1976) and Choudhuri and Banerji (1976) both considered the possibility that the veins at Kasipatnam are carbonatites, but settled on either hydrothermal skarn or pegmatite, respectively. Both noted the lack of abundant carbonates as one of the reasons to reject a carbonatitic origin. Our model does not require abundant carbonates as the deposit represents cumulate fluorapatites and the carbonatite liquid was transported elsewhere. The Kasipatnam veins are hosted in Fe-rich charnockites and clinopyroxene that occurs in these rocks are Fe-rich. However, the clinopyroxenes in the selvages grade to diopside the closer they are to the fluorapatite (Choudhuri and Banerji, 1976), in agreement with our model of introduced $\mathrm{Mg}$-rich carbonatite and with strikingly similar textures observed in figures 7B-7E, 7H, and 7M. Rao (1976) also notes elevated $\mathrm{Sr}$ and Ba contents in the diopside relative to the Fe-rich clinopyroxenes, which we suggest is further evidence for equilibration with carbonatitic melt.

CARBONATITE METASOMATISM

Formation of diopside by reaction with carbonatite melt is known to occur in the mantle. It was observed in mantle xenoliths of wehrlite and shown experimentally to form by the same mechanism of equation (3) (Wallace and Green, 1988; Dalton and Wood, 1993; Hammouda and Keshav, 2015; Gervasoni and others, 2017). These 
wehrlites are enriched in REE relative to their surrounding mantle rocks and commonly contain apatite (Green and Wallace, 1988; Yaxley and others, 1991; Hauri and others, 1993; Rudnick and others, 1993; Yaxley and others, 1998; Neumann and others, 2002; Su and others, 2010; Woodard and others, 2014). The wehrlitization process is commonly used to explain how magnesian carbonatites (and carbonatites in general) rise from mantle depths to escape the "carbonate ledge", which causes reaction of the carbonatite liquid with mantle rocks to release of $\mathrm{CO}_{2}$ (Dalton and Presnall, 1998; Hammouda and Keshav, 2015).

The fate of the carbonatites as they escape mantle depths has not been fully explored. An experimental study by Hammouda and others (2014) recreated decompression of a partially molten enstatite-dolomite mixture at high temperatures, avoiding the "carbonate ledge". The mixture melts to forsterite, diopside and carbonatitic liquid (essentially forming a wehrlite), and as pressure decreases to lower crustal depth equivalents, the liquid back-reacts with diopside to form forsterite, increasing the Ca proportion of the carbonatite. The study of Hammouda and others (2014) is isochemical, limiting its applicability to natural systems: crustal rocks are not wehrlites, but rather felsic granitoids. Formation of forsterite cannot happen in these rocks because the activity of $\mathrm{SiO}_{2}$ is too high. In contrast, our experiments show that a process similar to wehrlitization also occurs when a magnesian carbonatite reacts with typical crustal rocks: formation of diopside. In terms of phase relations, this reaction zone might not be different from skarns. Whereas some skarns form when silicate magma or derived fluids intrude a carbonate rock (see for example, Carter and Dasgupta, 2016), our experiments show the reaction of carbonatite magma with silicate rock: an "antiskarn". The mineral assemblage of our "antiskarns" (diopside, calcite, vesuvianite, wollastonite, also cuspidine, monticellite and magnesioferrite in run D2332) highly resembles the assemblage of hydrothermal skarns, raising the possibility that some skarns or mineralogically similar rocks may in fact be paleoconduits of carbonatite magma as it traversed the crust. For example, the Nolans-type deposit at Kasipatnam, which Rao (1976) suggested to be a skarn is more likely an "antiskarn".

\section{COMPARISON WITH FENITES AND ENDOSKARNS}

There are two other well-known processes that involve carbonate metasomatism of silicate rocks: fenitization and formation of endoskarns.

Fenitization is a well-recognized process in which aqueous alkali fluids exsolving from a carbonatite metasomatize the wall rocks, altering them to an assemblage of alkali feldspars, aegirine, and alkali amphiboles such as arfvedsonite and riebeckite (Pirajno, 2013; Elliott and others, 2018). Fenites, which commonly host REE and Nb mineralization, form when carbonatites are emplaced in the upper crust at depths of $10 \mathrm{~km}$ up to near-surface environments. Fluid temperatures range from 400 to $700{ }^{\circ} \mathrm{C}$, which corresponds to temperatures at which carbonatite melts solidify and decompress, releasing a separate fluid phase into which alkalis and some ore elements partition. This is commonly accompanied by hydrofracturing and brecciation (Elliott and others, 2018). Depending on the hydraulic properties of the wall rocks, fenitization can occur several hundreds of meters away from the carbonatite intrusion. Antiskarns, in contrast, are the result of the direct reaction between carbonatite liquid and silicate wall rocks, and the skarn-like assemblage is only centimeters to several meters wide. They form while alkalis and $\mathrm{H}_{2} \mathrm{O}$ are still dissolved in the carbonatite, and they are not required for antiskarnification as the process primarily exchanges $\mathrm{Ca}, \mathrm{Mg}$, $\mathrm{Al}, \mathrm{Si}$, and $\mathrm{Fe}$, rather than $\mathrm{Na}$ and $\mathrm{K}$. Antiskarns form at higher temperatures $(>700$ ${ }^{\circ} \mathrm{C}$ ) and pressures $(>5 \mathrm{kbar}$ or $\sim 15 \mathrm{~km}$ deep) than fenites. There is no brecciation, and the minerals formed at the reaction zone are calcic diopsides instead of alkaliferric aegirines. Grandite garnets and calcic amphiboles, not alkali amphiboles, form 
during later hydrothermal alteration. The alkali feldspar that primarily forms at the reaction zone is hyalophane, which forms by addition of $\mathrm{Ba}$ to pre-existing alkali feldspars in the wall rock. Minor albite may form if the temperature is low enough. Finally, the mineralization is confined to the interior of the vein and the reaction zone itself is barren (although later remobilization can transport REE to the diopside zones, for example, Schoneveld and others, 2015; Pandur and others, 2016).

The term "skarn" by itself has no genetic meaning and merely describes metasomatic rocks comprising a calc-silicate mineral assemblage, commonly containing significant Mg, Fe, and Al (Einaudi and Burt, 1982; Misra, 2000). Nevertheless, skarns are commonly discussed in the context of aqueous hydrothermal fluids exsolved from crystallizing intermediate to felsic plutons (Meinert, 1993; Misra, 2000; Pirajno, 2013). Endoskarns, in particular, are metasomatic domains that form inside the intruding plutons themselves, commonly in the contact with carbonate rocks (Einaudi and Burt, 1982; Misra, 2000). Our "antiskarn" remains faithful to the non-genetic term "skarn", as it contains the same mineral assemblage. However, the genetic term "endoskarn" implies the presence of a silicate intrusion and an aqueous fluid - neither of which are present in antiskarns. Alternatively, endoskarns may form by direct assimilation of carbonates by the silicate magmas at high temperatures (Di Rocco and others, 2012; Carter and Dasgupta, 2016). Like fenitic fluids, the skarn-forming metasomatic aqueous fluid exsolves due to decompression and crystallization of a pluton at shallow depths ( $<5$ kbar, Meinert, 1993), whereas the metasomatism of antiskarns results from direct reaction of a carbonatite with silicate wall rocks at mid-crustal depths $(>5$ kbar). This process resembles carbonatite metasomatism in the mantle more than formation of skarns in and around silicate intrusions in the upper crust. The presence of $\mathrm{H}_{2} \mathrm{O}$ is not required for antiskarn formation, although it helps flux the carbonatite to a liquid. Mineralization in most skarns consists of chalcophile elements: $\mathrm{Cu}, \mathrm{Mo}, \mathrm{Zn}$, $\mathrm{Pb}, \mathrm{Ag}, \mathrm{Au}$, et cetera, in association with sulfides. Non-sulfide $\mathrm{Fe}, \mathrm{W}$, and $\mathrm{Sn}$ mineralization also occurs in some skarns (Einaudi and Burt, 1982; Misra, 2000; Pirajno, 2013). This mineralization style is different than that of antiskarns, which consist of carbonatitemobile elements such as REE, Th, Ba, Sr, F, P, and possibly $\mathrm{Nb}$ and $\mathrm{Zr}$ (although not tested in our study). Although some carbonatites contain sulfide or sulfate, sulfur is not essential for the mineralization.

A schematic diagram (fig. 10) clarifies the difference between fenites, conventional hydrothermal skarns, and antiskarns.

CONCLUSIONS AND IMPLICATIONS

Large-scale transport of LREE by aqueous fluids in a phosphate-fluoride-rich system is ineffective and unlikely to form Nolans-type mineral systems. The composition and distribution of REE-phases observed in the hydrothermal experiments followed initial layer placement inside the capsule. REE migration within the capsules was negligible compared to all other elements in the experiments. REE-phases were commonly metastable and unreactive, demonstrating their low solubility. In contrast, magmatic experiments employing carbonatite as a REE carrier closely reproduced key features of the Nolans-type deposits. Firstly, fluorapatite contains a significant britholite component and formed without immiscibility. The carbonatite-silicate reaction produced selvages that mimick the diopsidic selvages observed in nature [given a ratio of $\mathrm{MgO} /(\mathrm{CaO}+\mathrm{MgO}) \approx 0.2$ in the carbonatite], with fluorapatites most abundant near the selvage.

Primary features of REE mineralization occurrences are commonly obscured by hydrothermal alteration, resulting in a pseudo-hydrothermal appearance. This alteration may lead workers to mistakenly conclude that REE were mobilized from source to the deposition site by aqueous fluids. The source may be the mantle or a hidden igneous intrusion. We show that the mode of REE transport must be carefully 


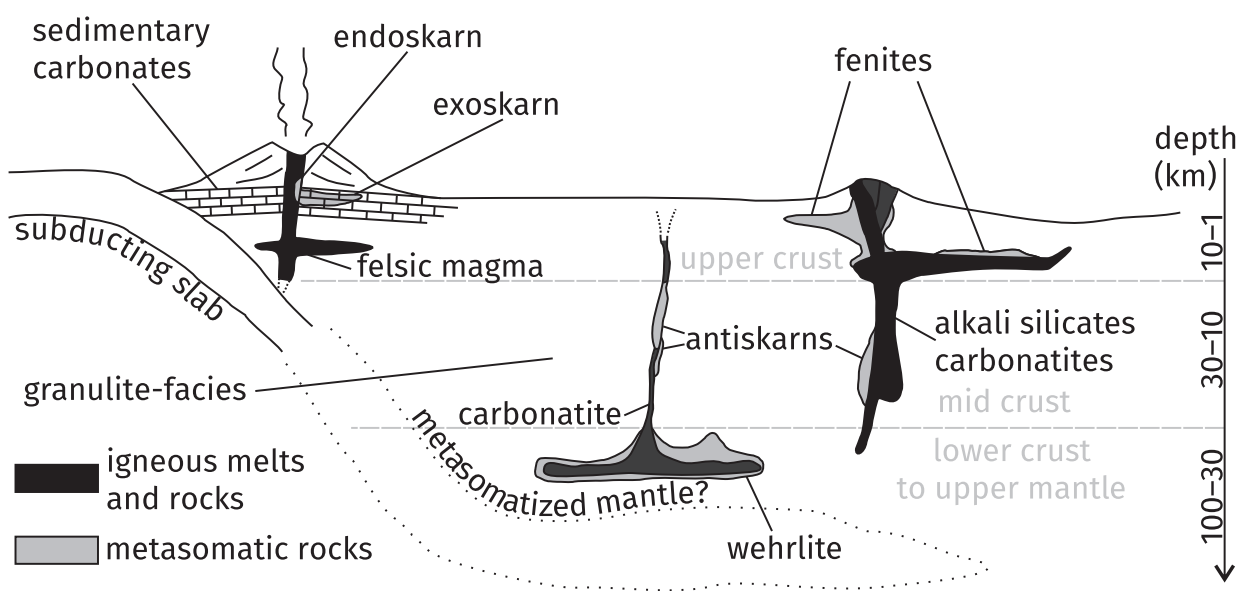

Fig. 10. A schematic sketch outlining the geological setting of hydrothermal endoskarns, fenites, and antiskarns.

considered, as REE are potentially insoluble in fluids containing the elements with which they precipitated at Nolans Bore. "Exotic" melts should be the principal mechanism considered: a carbonatite-derived residual cumulate in the case of Nolanstype deposits. Carbonatite liquids have low viscosity and strong wetting capabilities (McKenzie, 1985; Hunter and McKenzie, 1989; Hammouda and Laporte, 2000; Kono and others, 2014) — resembling aqueous fluids rather than silicate magmas-forming hydrothermal-like textures in otherwise magmatic systems. Furthermore, the solubility of $\mathrm{H}_{2} \mathrm{O}$ in carbonatites is known to be high, so a vapor phase only exsolves at a very late stage of carbonatite evolution (for example, Wyllie and others, 1996), at shallower levels than we suggest for Nolans-type deposit formation. Thus, the process of hydrothermal fluid exsolution from an unexposed magmatic source (as suggested by Huston and others, 2016, and Pandur and others, 2016) does not apply here because such a source does not exist, and Nolans-type veins represent an early (as opposed to late) stage in carbonatite evolution.

This fluid-like behavior of carbonatite melts and their reactivity with crustal rocks to form skarn-like assemblages in our experiments suggests this process may be overlooked in nature. Recognizing this process in natural rocks can shed light on mass transfer of carbonatite-mobile elements such as $\mathrm{P}, \mathrm{REE}$, Th, and $\mathrm{Ba}$ as in the case of Nolans-type deposits. More studies are required to understand this process of "antiskarnification", including experimental studies and re-evaluation of high-temperature skarn assemblages where the silicate fluid source is not immediately obvious.

\section{ACKNOWLEDGMENTS}

This research is supported by an Australian Government Research Training Program (RTP) Scholarship. Michael Anenburg acknowledges a Ringwood Scholarship from the Research School of Earth Sciences, Australian National University. Access to the facilities of the Centre for Advanced Microscopy (CAM), with funding through the Australian Microscopy and Microanalysis Research Facility (AMMRF), is gratefully acknowledged. We thank Kelvin Hussey and others at Arafura Resources for financial support and access to the Nolans Bore drill core collection, which inspired this experimental study. Jindřich Kynický and four other reviewers are acknowledged for critique that greatly improved this work. 


\section{REFERENCES}

Andersen, A. K., Clark, J. G., Larson, P. B., and Neill, O. K., 2016, Mineral chemistry and petrogenesis of a HFSE (+ HREE) occurrence, peripheral to carbonatites of the Bear Lodge alkaline complex, Wyoming: American Mineralogist, v. 101, n. 7, p. 1604-1623, https://doi.org/10.2138/am-2016-5532

Andrade, F. R. D., Möller, P., Lüders, V., Dulski, P., and Gilg, H. A., 1999, Hydrothermal rare earth elements mineralization in the Barra do Itapirapuã carbonatite, southern Brazil: Behaviour of selected trace elements and stable isotopes (C, O): Chemical Geology, v. 155, n. 1-2, p. 91-113, https://doi.org/ $10.1016 / \mathrm{s} 0009-2541(98) 00143-0$

Anenburg, M., Burnham, A. D., and Mavrogenes, J. A., 2018, REE redistribution textures in altered apatite: symplectites, veins and phosphate-silicate-carbonate assemblages from the Nolans Bore P-REE-Th deposit, NT, Australia: The Canadian Mineralogist, v. 56, n. 3, https://doi.org/10.3749/canmin. 1700038

Antignano, A., and Manning, C. E., 2008, Fluorapatite solubility in $\mathrm{H}_{2} \mathrm{O}$ and $\mathrm{H}_{2} \mathrm{O}-\mathrm{NaCl}$ at 700 to $900{ }^{\circ} \mathrm{C}$ and 0.7 to $2.0 \mathrm{GPa}$ : Chemical Geology, v. 251, n. 1-4, p. 112-119, https://doi.org/10.1016/j. chemgeo.2008.03.001

Atwood, D. A., 2012, The rare earth elements: fundamentals and applications: EIBC books: Chichester, West Sussex, United Kingdom; Hoboken, John Wiley \& Sons, Inc., 606 p.

Ayers, J. C., and Watson, E. B., 1991, Solubility of apatite, monazite, zircon, and rutile in supercritical aqueous fluids with implications for subduction zone geochemistry: Philosophical Transactions of the Royal Society A: Mathematical, Physical and Engineering Sciences, v. 335, n. 1638, p. 365-375, https://doi.org/10.1098/rsta.1991.0052

Baker, M. B., and Wyllie, P. J., 1992, High-pressure apatite solubility in carbonate-rich liquids: Implications for mantle metasomatism: Geochimica et Cosmochimica Acta, v. 56, n. 9, p. 3409-3422, https://doi.org/ 10.1016/0016-7037(92)90388-y

Bhatnagar, V. M., 1969, The melting points of synthetic apatites: Mineralogical Magazine, v. 37, n. 288, p. 527-528, http://www.minersoc.org/pages/Archive-MM/TOC/TOC37/TOC37_288.htm

Biggar, G. M., 1966, Experimental studies of apatite crystallization in parts of the system $\mathrm{CaO}-\mathrm{P}_{2} \mathrm{O}_{5}-\mathrm{H}_{2} \mathrm{O}$ at 1000 bars: Mineralogical Magazine, v. 36, n. 276, p. 1110-1122, https://doi.org/10.1180/ minmag.1966.036.276.06

1969, Phase relationships in the join $\mathrm{Ca}(\mathrm{OH})_{2}-\mathrm{CaCO}_{3}-\mathrm{Ca}_{3}\left(\mathrm{PO}_{4}\right)_{2}-\mathrm{H}_{2} \mathrm{O}$ at 1000 bars: Mineralogical Magazine, v. 37, n. 285, p. 75-82, https://doi.org/10.1180/minmag.1969.037.285.08

Bodeving, S., Williams-Jones, A. E., and Swinden, S., 2017, Carbonate-silicate melt immiscibility, REE mineralising fluids, and the evolution of the Lofdal Intrusive Suite, Namibia: Lithos, v. 268-271, p. 383-398, https://doi.org/10.1016/j.lithos.2016.11.024

Broom-Fendley, S., Styles, M. T., Appleton, J. D., Gunn, G., and Wall, F., 2016, Evidence for dissolutionreprecipitation of apatite and preferential LREE mobility in carbonatite-derived late-stage hydrothermal processes: American Mineralogist, v. 101, n. 3, p. 596-611, https://doi.org/10.2138/am-20165502CCBY

Broom-Fendley, S., Brady, A. E., Wall, F., Gunn, G., and Dawes, W., 2017, REE minerals at the Songwe Hill carbonatite, Malawi: HREE-enrichment in late-stage apatite: Ore Geology Reviews, v. 81, p. 23-41, https://doi.org/10.1016/j.oregeorev.2016.10.019

Budzyń, B., Harlov, D. E., Williams, M. L., and Jercinovic, M. J., 2011, Experimental determination of stability relations between monazite, fluorapatite, allanite, and REE-epidote as a function of pressure, temperature, and fluid composition: American Mineralogist, v. 96, n. 10, p. 1547-1567, https://doi.org/10.2138/ am.2011.3741

Bühn, B., Wall, F., and Le Bas, M. J., 2001, Rare-earth element systematics of carbonatitic fluorapatites, and their significance for carbonatite magma evolution: Contributions to Mineralogy and Petrology, v. 141, n. 5, p. 572-591, https://doi.org/10.1007/s004100100261

Carter, L. B., and Dasgupta, R., 2016, Effect of melt composition on crustal carbonate assimilation: Implications for the transition from calcite consumption to skarnification and associated $\mathrm{CO}_{2}$ degassing: Geochemistry, Geophysics, Geosystems, v. 17, n. 10, p. 3893-3916, https://doi.org/10.1002/ $2016 \mathrm{gc} 006444$

Chakhmouradian, A. R., and Zaitsev, A. N., 2012, Rare earth mineralization in igneous rocks: Sources and processes: Elements, v. 8, n. 5, p. 347-353, https://doi.org/10.2113/gselements.8.5.347

Choudhuri, R., and Banerji, K. C., 1976, On the occurrence, emplacement and origin of the apatite deposits of Kasipatnam in Visakhapatnam district, Andhra Pradesh: Proceedings of the Indian National Science Academy, v. 42-A, n. 5, p. 387-406, http://www.insa.nic.in/writereaddata/UpLoadedFiles/PINSA/ Vol42A_1976_5_Art07.pdf

Cooper, A. F., Gittins, J., and Tuttle, O. F., 1975, The system $\mathrm{Na}_{2} \mathrm{CO}_{3}-\mathrm{K}_{2} \mathrm{CO}_{3}-\mathrm{CaCO}_{3}$ at 1 kilobar and its significance in carbonatite petrogenesis: American Journal of Science, v. 275, n. 5, p. 534-560, https://doi.org/10.2475/ajs.275.534

Dalton, J. A., and Presnall, D. C., 1998, Carbonatitic melts along the solidus of model lherzolite in the system $\mathrm{CaO}-\mathrm{MgO}-\mathrm{Al}_{2} \mathrm{O}_{3}-\mathrm{SiO}_{2}-\mathrm{CO}_{2}$ from 3 to 7 GPa: Contributions to Mineralogy and Petrology, v. 131, n. 2-3, p. 123-135, https://doi.org/10.1007/s004100050383

Dalton, J. A., and Wood, B. J., 1993, The compositions of primary carbonate melts and their evolution through wallrock reaction in the mantle: Earth and Planetary Science Letters, v. 119, n. 4, p. 511-525, https://doi.org/10.1016/0012-821x(93)90059-i

Dasgupta, R., and Hirschmann, M. M., 2007, A modified iterative sandwich method for determination of near-solidus partial melt compositions. II. Application to determination of near-solidus melt compositions of carbonated peridotite: Contributions to Mineralogy and Petrology, v. 154, n. 6, p. 647-661, https://doi.org/10.1007/s00410-007-0214-8 
Di Rocco, T., Freda, C., Gaeta, M., Mollo, S., and Dallai, L., 2012, Magma chambers emplaced in carbonate substrate: Petrogenesis of skarn and cumulate rocks and implications for $\mathrm{CO}_{2}$ degassing in volcanic areas: Journal of Petrology, v. 53, n. 11, p. 2307-2332, https://doi.org/10.1093/petrology/egs051

Downs, R. T., 2006, The RRUFF Project: an integrated study of the chemistry, crystallography, Raman and infrared spectroscopy of minerals: Program and Abstracts of the 19th General Meeting of the International Mineralogical Association in Kobe, Japan, p. 3-13.

Einaudi, M. T., and Burt, D. M., 1982, Introduction-terminology, classification, and composition of skarn deposits: Economic Geology, v. 77, n. 4, p. 745-754, https://doi.org/10.2113/gsecongeo.77.4.745

Elliott, H. A. L., Wall, F., Chakhmouradian, A. R., Siegfried, P. R., Dahlgren, S., Weatherley, S., Finch, A. A., Marks, M. A. W., Dowman, E., and Deady, E., 2018, Fenites associated with carbonatite complexes: A review: Ore Geology Reviews, v. 93, p. 38-59, https://doi.org/10.1016/j.oregeorev.2017.12.003

Feng, M., Xu, C., Kynicky, J., Zeng, L., and Song, W., 2016, Rare earth element enrichment in Palaeoproterozoic Fengzhen carbonatite from the North China block: International Geology Review, v. 58, n. 15, p. 1940-1950, https://doi.org/10.1080/00206814.2016.1193774

Gervasoni, F., Klemme, S., Rohrbach, A., Grützner, T., and Berndt, J., 2017, Experimental constraints on mantle metasomatism caused by silicate and carbonate melts: Lithos, v. 282-283, p. 173-186, https:// doi.org/10.1016/j.lithos.2017.03.004

Gieré, R., 1996, Formation of rare earth minerals in hydrothermal systems, in Jones, A. P., Wall, F., and Williams, C. T., editors, Rare Earth Minerals: Chemistry, origin and ore deposits: London, Chapman \& Hall, p. 105-150.

Gorbachev, N. S., Shapovalov, Y. B., and Kostyuk, A. V., 2017, Experimental study of the apatite-carbonate$\mathrm{H}_{2} \mathrm{O}$ system at $P=0.5 \mathrm{GPa}$ and $T=1200{ }^{\circ} \mathrm{C}$ : Efficiency of fluid transport in carbonatite: Doklady Earth Sciences, v. 473, n. 1, p. 350-353, https://doi.org/10.1134/s1028334x17030230

Green, D. H., and Wallace, M. E., 1988, Mantle metasomatism by ephemeral carbonatite melts: Nature, v. 336, n. 6198 , p. $459-462$, https://doi.org/10.1038/336459a0

Hack, A. C., and Mavrogenes, J. A., 2006, A cold-sealing capsule design for synthesis of fluid inclusions and other hydrothermal experiments in a piston-cylinder apparatus: American Mineralogist, v. 91, n. 1, p. 203-210, https://doi.org/10.2138/am.2006.1898

Hammouda, T., and Keshav, S., 2015, Melting in the mantle in the presence of carbon: Review of experiments and discussion on the origin of carbonatites: Chemical Geology, v. 418, p. 171-188, https://doi.org/10.1016/j.chemgeo.2015.05.018

Hammouda, T., and Laporte, D., 2000, Ultrafast mantle impregnation by carbonatite melts: Geology, v. 28, n. 3, p. 283-285, http://dx.doi.org/10.1130/0091-7613(2000)28<283:UMIBCM > 2.0.CO;2

Hammouda, T., Chantel, J., and Devidal, J.-L., 2010, Apatite solubility in carbonatitic liquids and trace element partitioning between apatite and carbonatite at high pressure: Geochimica et Cosmochimica Acta, v. 74, n. 24, p. 7220-7235, https://doi.org/10.1016/j.gca.2010.09.032

Hammouda, T., Chantel, J., Manthilake, G., Guignard, J., and Crichton, W., 2014, Hot mantle geotherms stabilize calcic carbonatite magmas up to the surface: Geology, v. 42, n. 10, p. 911-914, https://doi.org/ $10.1130 / \mathrm{g} 35778.1$

Harlov, D. E., and Förster, H.-J., 2003, Fluid-induced nucleation of (Y+REE)-phosphate minerals within apatite: Nature and experiment. Part II. Fluorapatite: American Mineralogist, v. 88, n. 8-9, p. 1209-1229, https://doi.org/10.2138/am-2003-8-905

Harlov, D. E., Förster, H.-J., and Nijland, T. G., 2002, Fluid-induced nucleation of (Y + REE)-phosphate minerals within apatite: Nature and experiment. Part I. Chlorapatite: American Mineralogist, v. 87, n. 2-3, p. 245-261, https://doi.org/10.2138/am-2002-2-306

Harlov, D. E., Förster, H. J., and Schmidt, C., 2003, High $P$-T experimental metasomatism of a fluorapatite with significant britholite and fluorellestadite components: Implications for LREE mobility during granulite-facies metamorphism: Mineralogical Magazine, v. 67, n. 1, p. 61-72, https://doi.org/10.1180/ 0026461036710084

Harlov, D. E., Wirth, R., and Förster, H.-J., 2005, An experimental study of dissolution-reprecipitation in fluorapatite: Fluid infiltration and the formation of monazite: Contributions to Mineralogy and Petrology, v. 150, n. 3, p. 268-286, https://doi.org/10.1007/s00410-005-0017-8

Harlov, D. E., Wirth, R., and Hetherington, C. J., 2007, The relative stability of monazite and huttonite at 300-900 ${ }^{\circ} \mathrm{C}$ and $200-1000 \mathrm{MPa}$ : Metasomatism and the propagation of metastable mineral phases: American Mineralogist, v. 92, n. 10, p. 1652-1664, https://doi.org/10.2138/am.2007.2459

2011, Fluid-mediated partial alteration in monazite: The role of coupled dissolution-reprecipitation in element redistribution and mass transfer: Contributions to Mineralogy and Petrology, v. 162, n. 2, p. 329-348, https://doi.org/10.1007/s00410-010-0599-7

Hauri, E. H., Shimizu, N., Dieu, J. J., and Hart, S. R., 1993, Evidence for hotspot-related carbonatite metasomatism in the oceanic upper mantle: Nature, v. 365, n. 6443, p. 221-227, https://doi.org/10.1038/ $365221 \mathrm{a} 0$

Hermann, J., 2002, Allanite: Thorium and light rare earth element carrier in subducted crust: Chemical Geology, v. 192, n. 3-4, p. 289-306, https://doi.org/10.1016/s0009-2541(02)00222-x

Hetherington, C. J., Harlov, D. E., and Budzyń, B., 2010, Experimental metasomatism of monazite and xenotime: Mineral stability, REE mobility and fluid composition: Mineralogy and Petrology, v. 99, n. 3-4, p. 165-184, https://doi.org/10.1007/s00710-010-0110-1

Hoatson, D. M., Jaireth, S., and Miezitis, Y., 2011, The major rare-earth-element deposits of Australia: geological setting, exploration, and resources: Canberra, Australia, Geoscience Australia, 204 p., http://pid.geoscience.gov.au/dataset/71820

Hogarth, D. D., 1957, The apatite-bearing veins of Nisikkatch Lake Saskatchewan: The Canadian Mineralogist, v. 6, n. 1, p. 140-150, http://www.canmin.org/content/6/1/140

Holtstam, D., and Andersson, U. B., 2007, The REE minerals of the Bastnä S-type deposits, south-central 
Sweden: The Canadian Mineralogist, v. 45, n. 5, p. 1073-1114, https://doi.org/10.2113/gscanmin. 45.5.1073

Hunter, R. H., and McKenzie, D., 1989, The equilibrium geometry of carbonate melts in rocks of mantle composition: Earth and Planetary Science Letters, v. 92, n. 3-4, p. 347-356, https://doi.org/10.1016/ 0012-821x (89) 90059-9

Huston, D. L., Maas, R., Cross, A., Hussey, K. J., Mernagh, T. P., Fraser, G., and Champion, D. C., 2016, The Nolans Bore rare-earth element-phosphorus-uranium mineral system: Geology, origin and postdepositional modifications: Mineralium Deposita, v. 51, n. 6, p. 797-822, https://doi.org/10.1007/ s00126-015-0631-y

Jaireth, S., Hoatson, D. M., and Miezitis, Y., 2014, Geological setting and resources of the major rare-earthelement deposits in Australia: Ore Geology Reviews, v. 62, p. 72-128, https://doi.org/10.1016/ j.oregeorev.2014.02.008

Jones, A. P., and Wyllie, P. J., 1983, Low-temperature glass quenched from a synthetic, rare earth carbonatite: Implications for the origin of the Mountain Pass Deposit, California: Economic Geology, v. 78, n. 8, p. 1721-1723, https://doi.org/10.2113/gsecongeo.78.8.1721

Klemme, S., and Dalpé, C., 2003, Trace-element partitioning between apatite and carbonatite melt: American Mineralogist, v. 88, n. 4, p. 639-646, https://doi.org/10.2138/am-2003-0417

Kono, Y., Kenney-Benson, C., Hummer, D., Ohfuji, H., Park, C., Shen, G., Wang, Y., Kavner, A., and Manning, C. E., 2014, Ultralow viscosity of carbonate melts at high pressures: Nature Communications, v. 5, p. 5091, https://doi.org/10.1038/ncomms6091

Krasnova, N. I., Petrov, T. G., Balaganskaya, E. G., Garcia, D., Moutte, J., Zaitsev, A. N., and Wall, F., 2004, Introduction to phoscorites: Occurrence, composition, nomenclature and petrogenesis, in Zaitsev, A. N., and Wall, F., editors, Phoscorites and Carbonatites from Mantle to Mine: the Key Example of the Kola Alkaline Province: London, England, Mineralogical Society, Mineralogical Society Series, v. 10, https://doi.org/10.1180/MSS.10.02

Krenn, E., Harlov, D. E., Finger, F., and Wunder, B., 2012, LREE-redistribution among fluorapatite, monazite, and allanite at high pressures and temperatures: American Mineralogist, v. 97, n. 11-12, p. 1881-1890, https://doi.org/10.2138/am.2012.4005

Larsen, L. M., 1979, Distribution of REE and other trace elements between phenocrysts and peralkaline undersaturated magmas, exemplified by rocks from the Gardar igneous province, south Greenland: Lithos, v. 12, n. 4, p. 303-315, https://doi.org/10.1016/0024-4937(79)90022-7

Lee, W.-J., Fanelli, M. F., Cava, N., and Wyllie, P. J., 2000, Calciocarbonatite and magnesiocarbonatite rocks and magmas represented in the system $\mathrm{CaO}-\mathrm{MgO}-\mathrm{CO}_{2}-\mathrm{H}_{2} \mathrm{O}$ at $0.2 \mathrm{GPa}$ : Mineralogy and Petrology, v. 68, n. 4, p. 225-256, https://doi.org/10.1007/s007100050011

Linnen, R. L., Samson, I. M., Williams-Jones, A. E., and Chakhmouradian, A. R., 2014, Geochemistry of the rare-earth element, Nb, Ta, Hf, and Zr deposits, in Scott, S. D., editor, Geochemistry of Mineral Deposits: Treatise on Geochemistry (Second Edition), v. 13, p. 543-568, https://doi.org/10.1016/B9780-08-095975-7.01124-4

Louvel, M., Bordage, A., Testemale, D., Zhou, L., and Mavrogenes, J., 2015, Hydrothermal controls on the genesis of REE deposits: Insights from an in situ XAS study of Yb solubility and speciation in high temperature fluids $\left(\mathrm{T}<40{ }^{\circ} \mathrm{C}\right)$ : Chemical Geology, v. 417, p. 228-237, https://doi.org/10.1016/ j.chemgeo.2015.10.011

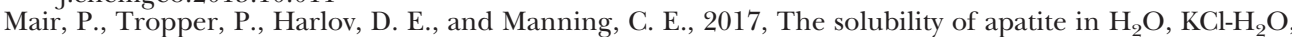
$\mathrm{NaCl}-\mathrm{H}_{2} \mathrm{O}$ at $800{ }^{\circ} \mathrm{C}$ and $1.0 \mathrm{GPa}$ : Implications for REE mobility in high-grade saline brines: Chemical Geology, v. 470, p. 180-192, https://doi.org/10.1016/j.chemgeo.2017.09.015

Martin, L. H. J., Schmidt, M. W., Mattsson, H. B., and Guenther, D., 2013, Element partitioning between immiscible carbonatite and silicate melts for dry and $\mathrm{H}_{2} \mathrm{O}$-bearing systems at 1-3 GPa: Journal of Petrology, v. 54, n. 11, p. 2301-2338, https://doi.org/10.1093/petrology/egt048

McKenzie, D., 1985, The extraction of magma from the crust and mantle: Earth and Planetary Science Letters, v. 74, n. 1, p. 81-91, https://doi.org/10.1016/0012-821x(85)90168-2

Meinert, L. D., 1993, Igneous petrogenesis and skarn deposits, in Kirkham, R. V., Sinclair, W. D., Thorpe, R. I., and Duke, J. M., editors, Mineral Deposit Modeling: Geological Association of Canada, Special Paper, v. 40, p. 569-583.

Migdisov, A. A., and Williams-Jones, A. E., 2014, Hydrothermal transport and deposition of the rare earth elements by fluorine-bearing aqueous liquids: Mineralium Deposita, v. 49, n. 8, p. 987-997, https:// doi.org/10.1007/s00126-014-0554-z

Migdisov, A., Williams-Jones, A. E., Brugger, J., and Caporuscio, F. A., 2016, Hydrothermal transport, deposition, and fractionation of the REE: Experimental data and thermodynamic calculations: Chemical Geology, v. 439, p. 13-42, https://doi.org/10.1016/j.chemgeo.2016.06.005

Misra, K. C., 2000, Skarn deposits, in Misra, K. C., editor, Understanding mineral deposits: Dordrecht, Springer, p. 414-449, https://doi.org/10.1007/978-94-011-3925-0_9

Narasayya, B. L., and Sriramadas, A., 1974, Apatite from apatite-magnetite deposits of Kasipatnam, Andhra Pradesh: Proceedings of the Indian Academy of Sciences - Section A, v. 80, n. 5, p. 207-210, https://doi.org/10.1007/BF03046711

Nassar, N. T., Du, X., and Graedel, T. E., 2015, Criticality of the rare earth elements: Journal of Industrial Ecology, v. 19, n. 6, p. 1044-1054, https://doi.org/10.1111/jiec.12237

Neumann, E. R., Wulff-Pedersen, E., Pearson, N. J., and Spencer, E. A., 2002, Mantle xenoliths from Tenerife (Canary Islands): Evidence for reactions between mantle peridotites and silicic carbonatite melts inducing Ca metasomatism: Journal of Petrology, v. 43, n. 5, p. 825-857, https://doi.org/10.1093/ petrology/43.5.825

Orris, G. J., and Grauch, R. I., 2002, Rare earth element mines, deposits, and occurrences: U.S. Geological Survey, Open-File Report 02-189, p. 174, http://pubs.usgs.gov/of/2002/of02-189/ 
Pan, Y., and Fleet, M. E., 2002, Compositions of the apatite-group minerals: Substitution mechanisms and controlling factors: Reviews in Mineralogy and Geochemistry, v. 48, n. 1, p. 13-49, https://doi.org/ 10.2138/rmg.2002.48.2

Panda, N. K., Rao, A. Y., Kumar, K. R., Mohanty, R., and Parihar, P. S., 2015, Anomalous REE concentration in carbonate-phosphate bearing phases from Narasimharajapuram area, Visakhapatnam district, Andhra Pradesh: Current Science, v. 109, n. 5, p. 860-862, http://www.currentscience.ac.in/php/ toc.php? vol $=109$ \&issue $=05$

Pandur, K., Kontak, D. J., and Ansdell, K. M., 2014, Hydrothermal evolution in the Hoidas Lake vein-type REE deposit, Saskatchewan, Canada: Constraints from fluid inclusion microthermometry and evaporate mound analysis: The Canadian Mineralogist, v. 52, n. 4, p. 717-744, https://doi.org/10.3749/ canmin. 1400005

Pandur, K., Ansdell, K. M., Kontak, D. J., Halpin, K. M., and Creighton, S., 2016, Petrographic and mineral chemical characteristics of the Hoidas Lake deposit, northern Saskatchewan, Canada: Constraints on the origin of a distal magmatic-hydrothermal REE system: Economic Geology, v. 111, n. 3, p. 667-694, https://doi.org/10.2113/econgeo.111.3.667

Pirajno, F., 2013, Effects of metasomatism on mineral systems and their host rocks: alkali metasomatism, skarns, greisens, tourmalinites, dodingites, black-wall alteration and listvenites, in Harlov, D. E., and Austrheim, H., editors, Metasomatism and the Chemical Transformation of Rock: Berlin, Heidelberg, Springer-Verlag, Lecture Notes in Earth System Sciences, p. 203-251, https://doi.org/10.1007/978-3642-28394-9_7

Pistone, M., Blundy, J. D., Brooker, R. A., and EIMF, 2016, Textural and chemical consequences of interaction between hydrous mafic and felsic magmas: An experimental study: Contributions to Mineralogy and Petrology, v. 171, n. 1, https://doi.org/10.1007/s00410-015-1218-4

Pourtier, E., Devidal, J.-L., and Gibert, F., 2010, Solubility measurements of synthetic neodymium monazite as a function of temperature at 2 kbars, and aqueous neodymium speciation in equilibrium with monazite: Geochimica et Cosmochimica Acta, v. 74, n. 6, p. 1872-1891, https://doi.org/10.1016/ j.gca.2009.12.023

Prokopyev, I. R., Doroshkevich, A. G., Ponomarchuk, A. V., and Sergeev, S. A., 2017, Mineralogy, age and genesis of apatite-dolomite ores at the Seligdar apatite deposit (Central Aldan, Russia): Ore Geology Reviews, v. 81, Part 1, p. 296-308, https://doi.org/10.1016/j.oregeorev.2016.10.012

Rao, A. T., 1976, Study of the apatite-magnetite veins near Kasipatnam, Visakhapatnam district, Andhra Pradesh, India: TMPM Tschermaks Mineralogische und Petrographische Mitteilungen, v. 23, n. 2, p. 87-103, https://doi.org/10.1007/bf01081477

Reed, S. J. B., and Ware, N. G., 1975, Quantitative electron microprobe analysis of silicates using energy-dispersive X-ray spectrometry: Journal of Petrology, v. 16, n. 3, p. 499-519, https://doi.org/ 10.1093/petrology/16.3.499

Robinson, B. W., Ware, N. G., and Smith, D. G. W., 1998, Modern electron-microprobe trace-element analysis in mineralogy, in Cabri, L. J., and Vaughan, D. J., editors, Modern approaches to ore and environmental mineralogy, v. 27: Ottawa, Mineralogical Association of Canada, Short Course 27, p. 153-180

Rudnick, R. L., McDonough, W. F., and Chappell, B. W., 1993, Carbonatite metasomatism in the northern Tanzanian mantle: Petrographic and geochemical characteristics: Earth and Planetary Science Letters, v. 114, n. 4, p. 463-475, https://doi.org/10.1016/0012-821x(93)90076-1

Ryabchikov, I. D., Orlova, G. P., Senin, V. G., and Trubkin, N. V., 1993, Partitioning of rare earth elements between phosphate-rich carbonatite melts and mantle peridotites: Mineralogy and Petrology, v. 49, n. 1-2, p. 1-12, https://doi.org/10.1007/BF01162922

Schoneveld, L., Spandler, C., and Hussey, K., 2015, Genesis of the central zone of the Nolans Bore rare earth element deposit, Northern Territory, Australia: Contributions to Mineralogy and Petrology, v. 170, n. 2, https://doi.org/10.1007/s00410-015-1168-x

Simandl, G. J., 2014, Geology and market-dependent significance of rare earth element resources: Mineralium Deposita, v. 49, n. 8, p. 889-904, https://doi.org/10.1007/s00126-014-0546-Z

Su, B.-X., Zhang, H.-F., Sakyi, P. A., Ying, J.-F., Tang, Y.-J., Yang, Y.-H., Qin, K.-Z., Xiao, Y., and Zhao, X.-M., 2010, Compositionally stratified lithosphere and carbonatite metasomatism recorded in mantle xenoliths from the Western Qinling (Central China): Lithos, v. 116, n. 1-2, p. 111-128, https://doi.org/ 10.1016/j.lithos.2010.01.004

Trofanenko, J., Williams-Jones, A. E., Simandl, G. J., and Migdisov, A. A., 2016, The nature and origin of the REE mineralization in the Wicheeda Carbonatite, British Columbia, Canada: Economic Geology, v. 111, n. 1, p. 199-223, https://doi.org/10.2113/econgeo.111.1.199

Verplanck, P. L., Mariano, A. N., and Mariano, A., Jr., 2016, Rare earth element ore geology of carbonatites, in Verplanck, P. L., and Hitzman, M. W., editors, Rare Earth and Critical Elements in Ore Deposits: Littleton, Colorado, USA, Society of Economic Geologists, Reviews in Economic Geology, v. 18, p. 5-32, https://doi.org/10.5382/Rev.18.01

Vidal, O., Goffé, B., and Arndt, N., 2013, Metals for a low-carbon society: Nature Geoscience, v. 6, n. 11, p. 894-896, https://doi.org/10.1038/ngeo1993

Wall, F., 2014, Rare earth elements, in Gunn, G., editor, Critical Metals Handbook: Oxford, John Wiley \& Sons, p. 312-339, https://doi.org/10.1002/9781118755341.ch13

Wall, F., and Mariano, A. N., 1996, Rare earth minerals in carbonatites: a discussion centred on the Kangankunde Carbonatite, Malawi, in Jones, A. P., Wall, F., and Williams, C. T., editors, Rare Earth Minerals: Chemistry, origin and ore deposits: London, Chapman \& Hall, p. 193-226.

Wallace, M. E., and Green, D. H., 1988, An experimental determination of primary carbonatite magma composition: Nature, v. 335, n. 6188, p. 343-346, https://doi.org/10.1038/335343a0

Walters, A. S., Goodenough, K. M., Hughes, H. S. R., Roberts, N. M. W., Gunn, A. G., Rushton, J., and 
Lacinska, A., 2013, Enrichment of rare earth elements during magmatic and post-magmatic processes: A case study from the Loch Loyal Syenite Complex, northern Scotland: Contributions to Mineralogy and Petrology, v. 166, n. 4, p. 1177-1202, https://doi.org/10.1007/s00410-013-0916-z

Ware, N. G., 1991, Combined energy-dispersive-wavelength-dispersive quantitative electron microprobe analysis: X-Ray Spectrometry, v. 20, n. 2, p. 73-79, https://doi.org/10.1002/xrs.1300200207

Weidendorfer, D., Schmidt, M. W., and Mattsson, H. B., 2017, A common origin of carbonatite magmas: Geology, v. 45, n. 6, p. 507-510, https://doi.org/10.1130/g38801.1

Weng, Z., Jowitt, S. M., Mudd, G. M., and Haque, N., 2015, A detailed assessment of global rare earth element eesources: Opportunities and challenges: Economic Geology, v. 110, n. 8, p. 1925-1952, https://doi.org/ 10.2113/econgeo.110.8.1925

Weng, Z. H., Jowitt, S. M., Mudd, G. M., and Haque, N., 2013, Assessing rare earth element mineral deposit types and links to environmental impacts: Applied Earth Science, v. 122, n. 2, p. 83-96, https://doi.org/ $10.1179 / 1743275813 y .0000000036$

Whitney, D. L., and Evans, B. W., 2010, Abbreviations for names of rock-forming minerals: American Mineralogist, v. 95, n. 1, p. 185-187, https://doi.org/10.2138/am.2010.3371

Williams-Jones, A. E., Migdisov, A. A., and Samson, I. M., 2012, Hydrothermal mobilisation of the rare rarth rlements - a tale of "Ceria" and "Yttria": Elements, v. 8, n. 5, p. 355-360, https://doi.org/10.2113/ gselements.8.5.355

Woodard, J., Kietäväinen, R., and Eklund, O., 2014, Svecofennian post-collisional shoshonitic lamprophyres at the margin of the Karelia Craton: Implications for mantle metasomatism: Lithos, v. 205, p. 379-393, https://doi.org/10.1016/j.lithos.2014.06.021

Wyllie, P. J., Cox, K. G., and Biggar, G. M., 1962, The habit of apatite in synthetic systems and igneous rocks: Journal of Petrology, v. 3, n. 2, p. 238-243, https://doi.org/10.1093/petrology/3.2.238

Wyllie, P. J., Jones, A. P., and Deng, J., 1996, Rare-earth elements in carbonate-rich melts from mantle to crust, in Jones, A. P., Wall, F., and Williams, C. T., editors, Rare Earth Minerals: Chemistry, origin and ore deposits: London, Chapman \& Hall, p. 77-103.

Xu, C., Kynicky, J., Chakhmouradian, A. R., Campbell, I. H., and Allen, C. M., 2010, Trace-element modeling of the magmatic evolution of rare-earth-rich carbonatite from the Miaoya deposit, Central China: Lithos, v. 118, n. 1-2, p. 145-155, https://doi.org/10.1016/j.lithos.2010.04.003

Xu, C., Kynicky, J., Chakhmouradian, A. R., Li, X., and Song, W., 2015, A case example of the importance of multi-analytical approach in deciphering carbonatite petrogenesis in South Qinling orogen: Miaoya rare-metal deposit, central China: Lithos, v. 227, p. 107-121, https://doi.org/10.1016/j.lithos.2015.03.024

Yaxley, G. M., Crawford, A. J., and Green, D. H., 1991, Evidence for carbonatite metasomatism in spinel peridotite xenoliths from western Victoria, Australia: Earth and Planetary Science Letters, v. 107, n. 2, p. 305-317, https://doi.org/10.1016/0012-821x(91)90078-v

Yaxley, G. M., Green, D. H., and Kamenetsky, V., 1998, Carbonatite metasomatism in the southeastern Australian lithosphere: Journal of Petrology, v. 39, n. 11-12, p. 1917-1930, https://doi.org/10.1093/ petroj/39.11-12.1917

Zaitsev, A. N., Williams, C. T., Jeffries, T. E., Strekopytov, S., Moutte, J., Ivashchenkova, O. V., Spratt, J., Petrov, S. V., Wall, F., Seltmann, R., and Borozdin, A. P., 2014, Rare earth elements in phoscorites and carbonatites of the Devonian Kola Alkaline Province, Russia: Examples from Kovdor, Khibina, Vuoriyarvi and Turiy Mys complexes: Ore Geology Reviews, v. 61, p. 204-225, https://doi.org/10.1016/ j.oregeorev.2014.02.002

Zhou, L., Mavrogenes, J., Spandler, C., and Li, H., 2016, A synthetic fluid inclusion study of the solubility of monazite-(La) and xenotime-(Y) in $\mathrm{H}_{2} \mathrm{O}-\mathrm{Na}-\mathrm{K}-\mathrm{Cl}-\mathrm{F}-\mathrm{CO}_{2}$ fluids at $800{ }^{\circ} \mathrm{C}$ and $0.5 \mathrm{GPa}$ : Chemical Geology, v. 442, p. 121-129, https://doi.org/10.1016/j.chemgeo.2016.09.010 